\title{
Vulnerabilidad alimentaria y política agroalimentaria en México
}

\author{
Humberto González Chávez y Alejandro Macías Macías
}

Con base en el concepto de vulnerabilidad alimentaria se analizan las implicaciones que, en los últimos veinticinco años, ha tenido la política agroalimentaria de México en el acceso sustentable de la población a una alimentación suficiente, nutritiva y saludable. Este análisis considera tanto factores de orden natural (diversidad genética, cambio climático y degradación ambiental), como económico (autosuficiencia alimentaria e importación y exportación de alimentos) y social (movilidad de la población, ingreso y niveles de pobreza). Concluye que la política agroalimentaria en México ha contribuido a una mayor vulnerabilidad alimentaria de la población mexicana en el corto y mediano plazo.

PALABRAS CLAVE: vulnerabilidad, política agroalimentaria, seguridad alimentaria, sustentabilidad de la agricultura

\section{Nutritional Vulnerability and Mexico's Agro-Alimentary Policy}

Based on the concept of nutritional vulnerability, this paper studies the effects of Mexico's agroalimentary policy on the population's sustainable access to an adequate, nourishing and healthy nutrition during the last twenty-five years. This analysis takes into consideration natural factors (genetic diversity, climate change and environmental degradation), economic factors (food self-sufficiency and food importation and exportation), as well as social factors (population mobility, income and poverty levels). It concludes that Mexico's agro-alimentary policy has deepened the population's nutritional vulnerability for the short and medium term.

KEY WORDS: vulnerability, agro-alimentary policy, food security, agricultural sustainability

\footnotetext{
HUMBERTO GONZÁLEZ CHÁVEZ: Centro de Investigaciones y Estudios Superiores en Antropología Social-Occidente, Guadalajara, Jalisco, México. hgc@ciesas.edu.mx

ALEJANDRO MACÍAS MACíAS: Universidad de Guadalajara, Guadalajara, México. alejandrom@cusur.udg.mx
} 
$\mathrm{E}$ 1 concepto de seguridad alimentaria, desde su formulación en 1974 en la Conferencia Mundial para la Alimentación, ha propiciado numerosos debates en foros nacionales e internacionales en los que se han incorporado diversos problemas relacionados con la agricultura, las políticas públicas, el medio ambiente, el derecho internacional, los derechos humanos, entre otros. Estas polémicas han aportado significados al término, pero también mucha ambigüedad (Braun et al., 1992; Torres, 2003; Maxwell, 1996). Por ello, en este trabajo hemos dejado de lado este concepto para evaluar los resultados de la política agrícola de México en las últimas dos décadas y hemos adoptado el de vulnerabilidad agroalimentaria. El de seguridad alimentaria, además de su ambigüedad, sólo hace referencia a la disponibilidad de los alimentos sin considerar la producción de los mismos; ambos elementos — producción y disponibilidad de los alimentos - son interdependientes y están condicionados por factores ambientales; de ahí que deban ser explícitamente tomados en cuenta. Por otra parte, el término de seguridad alimentaria nos propone un estado utópico del desarrollo, ya que la mayor parte de los seres humanos experimentan una inseguridad alimentaria y los esfuerzos internacionales para aliviarla han tenido resultados magros (véase González, en este número). Esta perspectiva utópica sobre la alimentación inhibe una conciencia crítica (Beck, 1997), además de una corresponsabilidad y una acción eficaz para afrontar los riesgos y las amenazas que se ciernen sobre una problemática fundamental para la sobrevivencia de la humanidad. Los nuevos desarrollos tecnológicos, las ideologías del desarrollo en boga, los cambios en la organización y división del trabajo, el cambio climático, la mayor articulación global y, en general, los derroteros que sigue el desarrollo agrícola y alimentario, plantean riesgos, particularmente para la población más vulnerable. Éstos deben ser conocidos y enfrentados de forma extensa y eficaz, tanto en sus manifestaciones, como en su origen y fundamento.

El concepto de vulnerabilidad, según quienes lo han desarrollado teóricamente (Blaikie et al., 1996: 33-36; García, 2005), nos plantea una situación de cambios continuos que se deben analizar históricamente para evaluar el peso y la duración que tiene la combinación de los fac- tores naturales y sociales que los producen; asimismo, se debe situar espacial y socialmente a la población vulnerable de acuerdo con la edad, el género y la salud física o mental, además de criterios socioculturales como etnicidad y clase social. Esta territorialización debe hacerse teniendo en cuenta no sólo el riesgo o la amenaza que existe para cada uno de los segmentos sociales, sino también su capacidad de respuesta y recuperación (Moser, 1996: 24). Además, se debe considerar la acumulación y combinación de desventajas que impiden a un grupo o sector de la población utilizar sus recursos económicos y sociales para enfrontar situaciones de riesgo y recuperarse (González, 2006).

La vulnerabilidad agroalimentaria, en particular, debe considerar fenómenos cíclicos -inundaciones, ciclones, sequías o terremotos- y fenómenos eventuales - epidemias, guerras, plagas o enfermedades del ganado o de los cultivos que pueden originarse por condiciones naturales, pero también por prácticas agrícolas insustentables, como la contaminación del medio ambiente y de los alimentos y el abatimiento de los recursos naturales-. Finalmente, puede presentarse en forma progresiva y constante, como la erosión del suelo, la desertificación, el cambio climático, la disminución de la biodiversidad de los cultivos; o de manera súbita, como un cambio en las políticas agroalimentarias que mina la capacidad productiva de un país y lesiona el poder adquisitivo y la capacidad de recuperación de amplios sectores de su población. Este último impacto es el que nos proponemos estudiar en el presente trabajo.

Por vulnerabilidad agroalimentaria entenderemos aquí la situación que caracteriza a países, sectores sociales, grupos e individuos que están expuestos o son susceptibles de padecer hambre, desnutrición o enfermedad por no tener acceso física, económica y sustentablemente a una alimentación suficiente, nutritiva y culturalmente aceptable, o por consumir productos insalubres o contaminados. Esta definición recoge elementos propuestos por la Organización de las Naciones Unidas para la Agricultura y la Alimentación (FAO) en sus documentos (1975, 1983 y 1996) y permite precisar la vulnerabilidad agroalimentaria de la población del norte y del sur hemisférico.

Este concepto, según lo veremos a lo largo de este tra- 


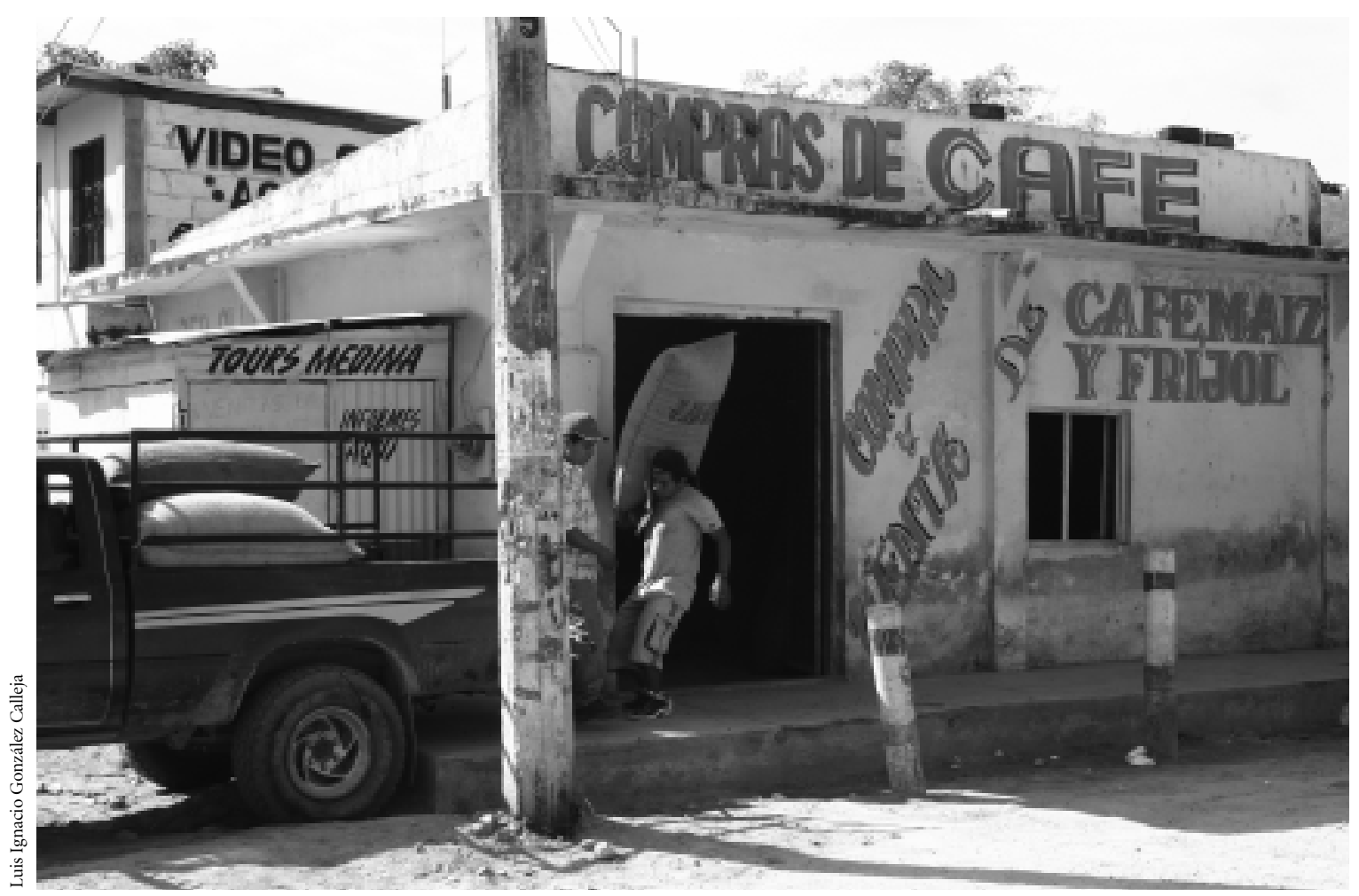

"Coyotes" en la comercialización de los productos de campesinos indígenas.

bajo, posibilita caracterizar la problemática agroalimentaria según diferentes escalas del continuum local-global; contempla la articulación, coordinación e interdependencia tanto de los que producen y comercializan los alimentos, como de quienes los consumen; considera el inventario y la disponibilidad de los alimentos, así como el acceso constante y efectivo a ellos por parte de los diferentes sectores y grupos sociales y de los individuos más frágiles o con desventajas acumuladas; además, permite valorar el riesgo ambiental, económico y político de medidas tales como la especialización productiva en unos cuantos cultivos o variedades de ellos, así como el de la concentración de la exportación y/o importación de alimentos en un solo país. Lleva a considerar la viabilidad económica, social y cultural de los pequeños productores de autoabasto y la urgencia de resguardar el patrimonio cultural y biogenético que poseen, en contraposición con la gran empresa agroalimentaria, que busca aumentar constantemente la producción y ser competitiva en el mercado nacional e internacional, sin reparar en los costos y consecuencias ambientales y sociales que tienen sus acciones en el mediano y largo plazo.

El análisis de la relación entre vulnerabilidad agroalimentaria y política económica en México lo abordaremos en tres renglones básicos. El primero considera las condiciones agropecuarias y económicas de producción que posibilitan un abasto suficiente y oportuno de alimentos para la población. El segundo se refiere a las condiciones ambientales que permiten el uso sustentable de los recursos naturales para asegurar la alimentación de la población presente y futura. Finalmente, el tercero considera las condiciones sociales que nos permiten precisar los sectores de la población que padecen o son susceptibles de sufrir desnutrición y hambre. Antes de entrar en esta materia caracterizaremos la trayectoria de la política agroalimentaria de México. 


\section{El contexto internacional de la política de México}

Actualmente México es considerado un caso paradigmático en los estudios de desarrollo porque ha aplicado radicalmente la política de apertura y liberalización económica, además de firmar el mayor número de tratados comerciales en el mundo. Resalta particularmente el que estableció con Estados Unidos y Canadá, países con los que tenía y tiene grandes diferencias económicas, y sin establecer un fondo compensatorio que las aliviara.

En México la meta de lograr una producción alimentaria propia para cubrir la demanda de la población dejó de ser una prioridad desde mediados de la década de 1980. Este viraje en la política alimentaria está asociado a un cambio en la ideología del desarrollo, que guió las acciones de la nueva élite burocrática y del Fondo Monetario Internacional (FMI) (González, 1998; y González, en la presentación de este número). La nueva ideología del desarrollo a partir de la cual se diseñó, justificó y evaluó la política agropecuaria concedió un peso fundamental dad en el mercado internacional. Con base en estos criterios se recurrió a la desregulación económica y la apertura comercial como principal estrategia de "desarrollo". Las desigualdades económicas, sociales y territoriales, la concentración del poder y de los beneficios en manos de las empresas transnacionales, la degradación ambiental que acompaña a la intensificación agrícola y a los monocultivos de exportación, etcétera, fueron minimizados o se consideraron "externalidades" y efectos transitorios de un "nuevo" orden económico mundial.

Dos hechos fundamentales marcan la nueva orientación económica y comercial del país. El primero ocurrió en 1986, cuando México pasó a formar parte del Acuerdo General de Aranceles y Comercio (GATT), lo que implicó la reducción abrupta de las restricciones y barreras arancelarias sin una política de apoyo a los sectores imposibilitados para enfrentar la competencia internacional (Calva, 1993 y 1994); el segundo fue la firma del Tratado de Libre Comercio de América del Norte (TLCAN) en 1994, cuyas negociaciones se realizaron sin la participación efectiva de los sectores productivos agrícola y pecuario.
A diferencia de los países desarrollados del norte y con la premisa de que el desarrollo agrícola más eficiente se alcanza cuando hay un mercado libre de intervensionismos, el gobierno mexicano ha venido reduciendo en números reales el presupuesto de los sectores agropecuario y pesquero desde 1982 hasta el presente. En 1981 el gasto programable del gobierno federal en agricultura, ganadería y pesca representó $1.37 \%$ del producto interno bruto (PIB), cifra de por sí demasiado baja si se considera que en aquel año este sector aportaba alrededor de 6.5\% del PIB y daba ocupación a una cuarta parte de la población. Sin embargo, conjuntamente con la crisis económica de la década de 1980, el presupuesto destinado a la agricultura decreció ostensiblemente hasta representar sólo 0.44\% del PIB en 1999, para recuperarse ligeramente durante el gobierno del presidente Vicente Fox y terminar en $0.53 \%$ en $2006^{1}$.

Otra estrategia del gobierno federal para que la agricultura se orientara de acuerdo con las "fuerzas del mercado" fue el cierre y la privatización de prácticamente todas las empresas paraestatales y los organismos que daban apoyo al sector agropecuario, ya fuera en la parte de producción (como Fertilizantes de México y el Banco Nacional de Crédito Rural) o en la de comercialización (como fue el caso de la Compañía Nacional de Subsistencias Populares).

De igual manera, el crédito agrícola otorgado por la banca de desarrollo inició desde 1983 un franco retroceso (cuadro 1). Aun así, el crecimiento del crédito por parte de la banca comercial hasta 1994 permitió que el crédito total siguiera aumentando. Sin embargo, la crisis financiera y bancaria que inició en el campo en 1992 y se recrudeció en 1995 tuvo como consecuencia la drástica y constante disminución del crédito comercial, que cayó a una tasa anual promedio de $18.69 \%$ entre 1994 y 2000 , y $12.12 \%$ entre 2000 y 2007. Si a ello agregamos el drástico descenso del crédito que ofrece la banca de desarrollo, entonces en general el crédito al sector agrope-

\footnotetext{
${ }^{1}$ Secretaría de Hacienda y Crédito Público (SHCP), Dirección General Adjunta de Estadística de la Hacienda Pública, en: <www.shacp.gob. $\mathrm{mx}>$, consultado el 20 de mayo de 2007.
} 
Cuadro 1. Crédito al sector agropecuario, silvicultura y pesca

\begin{tabular}{l|c|c|c}
\hline & \multicolumn{2}{|c}{ Promedio mensual (millones de pesos de la segunda quincena de junio de 2002) } \\
\hline Periodo & Banca comercial ${ }^{*}$ & Banca de desarrollo & Total \\
\hline $1983-1990$ & 51151 & 62015 & 113165 \\
\hline $1990-1994$ & 108799 & 39402 & 1481 \\
\hline $1995-2000$ & 76170 & 26366 & 336 \\
\hline $2001-2007$ & 21947 & 8354 & 300 \\
\hline $1994-2007^{* *}$ & 54303 & 18466 & 768 \\
\hline $1983-1990$ & $11.10 \%$ & $-3.50 \%$ & $3.50 \%$ \\
\hline $1990-1994$ & $17.00 \%$ & $-3.80 \%$ & $10.50 \%$ \\
\hline $1994-2000$ & $-18.69 \%$ & $-15.42 \%$ & $-17.92 \%$ \\
\hline $2000-2007$ & $-12.12 \%$ & $-39.40 \%$ & $-15.53 \%$ \\
\hline $1994-2007$ & $-15.21 \%$ & $-29.32 \%$ & $-16.64 \%$ \\
\hline
\end{tabular}

* Incluye los préstamos otorgados por agencias del extranjero.

** Hasta marzo de 2007.

FUENTE: Para los periodos 1983-1990 y 1990-1994: Yunes-Naude (2002). Para el resto de la información: Banco de México, "Relación de responsabilidades de usuarios del crédito bancario y balances bancarios" (<http://www.banxico.org.mx/polmoneinflacion/estadisticas/financBalanIntermFinan/financBalanIntermFinan.html >, consultado el 25 de mayo de 2007).

cuario ha caído a una tasa promedio anual de $16.64 \%$ entre 1994 y 2007 (cuadro 1).

Las consecuencias negativas que tiene el retraimiento del crédito al campo se intensifican por el hecho de que en los últimos veinte años el apoyo gubernamental a los productores agropecuarios ha tenido marcadas fluctuaciones de unos años a otros, lo que ha creado desequilibrios e incertidumbre en el sector (gráfica 1, p. 52). Además, en promedio este apoyo está por debajo del que otorgan a sus productores la Unión Europea, Canadá y Estados Unidos, e incluso, en este último país, sus subsidios fueron superiores durante la década de 1980 y la segunda mitad de la de 1990, cuando en México se dispararon las tasas de interés y la gran inestabilidad financiera afectó a la economía en su conjunto (Garrido y Leriche, 1998; Girón, 1994)². De esta forma, los productores

\footnotetext{
${ }^{2}$ Cabe señalar que, a pesar de lo revelador que resultan los datos que presenta la Organización para la Cooperación y el Desarrollo Económico (OCDE), un aspecto a tener en cuenta es que sus estimaciones no
}

mexicanos enfrentan una competencia desigual tanto en el mercado interno como en el de exportación, lo que socava su capacidad productiva y crea una situación de vulnerabilidad en el contexto global.

Antes de entrar al análisis de la vulnerabilidad agroalimentaria nos interesa resaltar que la ideología del desarrollo adoptada por el gobierno de México presenta simplificaciones e inconsistencias que consideramos importante resaltar. En primer lugar, concede un papel secundario a la interdependencia entre sociedad y medio ambiente y pierde de vista la especificidad de la agricultura frente a las demás actividades económicas, por el hecho de trabajar con seres orgánicos que cumplen un

hacen un ajuste con relación al tipo de cambio. Así, en un periodo de sobrevaluación, como sucedió en México entre 1991 y 1994 y de manera reciente en los últimos años, los apoyos pueden parecer superiores a lo que en realidad son. Igualmente, durante la devaluación de 1995 y 1996, los apoyos mostrados en la gráfica 1 (p. 52), manifiestan un descenso considerable. 
Gráfica 1. Apoyos promedio al productor agropecuario como porcentaje del valor de la producción

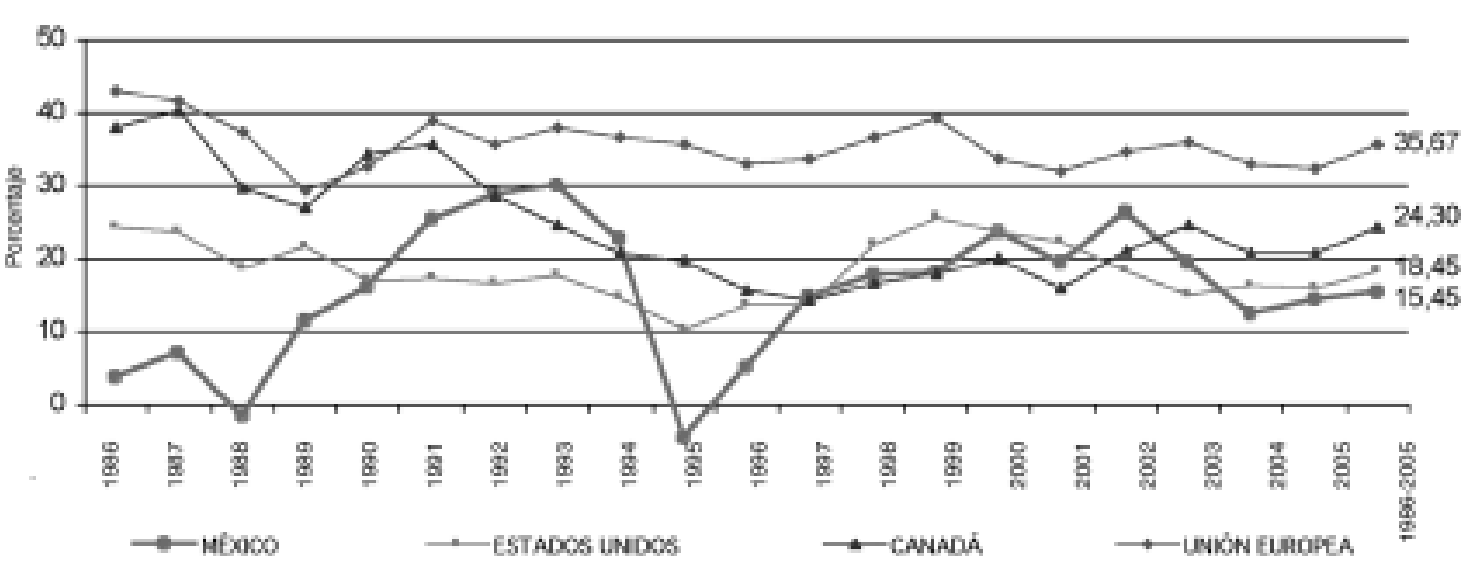

Fuente: Producer and Consumer Support Estimates, OECD Databases, 2006

ciclo de vida y se desarrollan en condiciones climáticas y ambientales sobre las que el hombre no tiene control (Goodman y Redclift, 1991; Redclift, 1997; Sevilla, 2006). En segundo lugar, esta ideología olvida que la agricultu-

ra, como cualquier otra actividad económica, se desarrolla en contextos históricos y sociales específicos (Polanyi, 1957), en los que el mercado es una construcción política y no una institución económica autorregulada basada en el interés propio y en la competitividad. Finalmente, es simplista porque concibe un desarrollo económico centrado en individuos atomizados que guían sus acciones en razón de una racionalidad de costo-beneficio o adoptan un orden institucional externo a ellos, sin considerar los diferentes contextos sociales y culturales en los que se desenvuelven, los cuales definen el rango de posibilidad sobre los que ellos actúan (Granovetter, 1985 y 1992).

En el marco de la intensa apertura comercial y desregulación económica, la sociedad nacional presenta una mayor vulnerabilidad agroeconómica, ambiental y social.

\section{LA VULNERABILIDADY LAS CONDICIONES AGROECONÓMICAS}

Para evaluar esta problemática consideramos importante analizar cuál ha sido en las dos últimas décadas el comportamiento de la producción agropecuaria, la balanza comercial agrícola y la concentración geográfica de las importaciones y las exportaciones agropecuarias, así como la capacidad competitiva de los productores de granos básicos para la alimentación en el contexto de competencia mundial.

\section{La producción agropecuaria}

En términos generales, en México ha habido un incremento en la productividad del sector alimentario, aunque éste cada vez tiene menos importancia en el PIB, particularmente a partir de la entrada de México al GATT y a raíz de las posteriores políticas agrícolas. Mientras que en 1986 el sector alimentario mexicano participaba con 11.37\% del PIB, en 1994 la cifra era de 10.26\% y en 2006 de sólo $9.71 \%{ }^{3}$. Esta pérdida de importancia del sector alimentario en la economía ha llevado en México, al igual que en otros países, a desvalorizar su contribución al bienestar de la población y a suprimir el valor estratégico que anteriormente se le concedía al asociar la seguridad

\footnotetext{
${ }^{3}$ Instituto de Estadística, Geografía e Informática (INEGI), Banco de Información Económica, en <http://dgcnesyp.inegi.gob.mx/>, consultado entre el 15 y el 31 de mayo de 2007.
} 
Gráfica 2. Tasas de crecimiento promedio anual por grupos de productos en México (1961-2005)

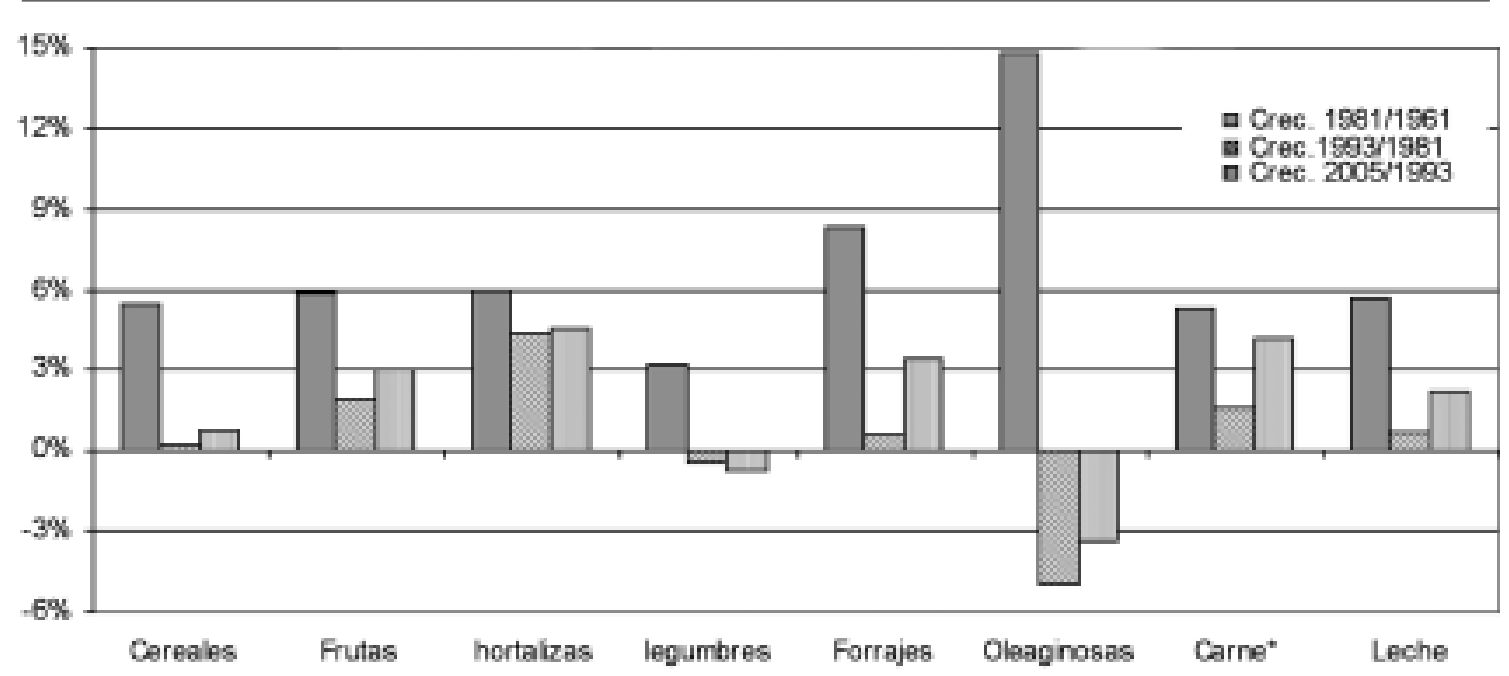

* Incluye carne de bovino, pocino, caprino, ovino y pollo.

FUENTE: Elaborado con base en FAO, Faostat (<www.faostat.org $>$, consultado el 21 de mayo de 2007).

nacional con la "seguridad alimentaria" y al postular la "autonomía alimentaria" como objetivo clave de política pública.

Las tasas de crecimiento mexicanas en la producción de los principales grupos de productos agropecuarios en el periodo de 1961 a 1981 eran relativamente altas, pues con excepción de las legumbres, en todos los demás rubros la producción crecía más de $5 \%$ anual (gráfica 2). Sin embargo, de 1982 a 1993, periodo que incluye la llamada "crisis de la deuda" que sacudió a México y buena parte de América Latina, el crecimiento de la producción descendió considerablemente, siendo incluso negativo en el caso de las legumbres y oleaginosas, en las que desde esas fechas el país se ha vuelto cada vez más dependiente.

En el periodo de 1994 a 2005 el crecimiento de la producción mexicana fue inferior a 3\% anual en casi todos los rubros, con excepción de las hortalizas, forrajes, frutas y carnes. La disminución en el ritmo de crecimiento de la producción apunta a una menor autosuficiencia alimentaria, toda vez que ello ha hecho descender la producción agropecuaria per cápita. En efecto, como puede verse en el cuadro 2 (p. 54), el PIB de este sector por ha- bitante ha descendido casi 7\% entre 1980 y 2005, cifra que podría haber sido peor de no haberse presentado una ligera recuperación en el último quinquenio.

Además, el descenso de la producción por falta de competitividad de los agricultores y ganaderos mexicanos puede verse más nítidamente en los principales productos. En ocho de los trece productos o grupos de ellos contemplados en el cuadro 2 (p. 54) la producción per cápita ha disminuido en el periodo de 1980 a 2005, siendo dramáticos los casos del frijol y las leguminosas en general, el trigo y el arroz, aunque también antes de entrar en vigor el TLCAN manifestaban descensos las carnes porcina y bovina, así como la leche.

Del lado contrario, el crecimiento de la producción per cápita en cuatro de los cinco productos del cuadro 2 (p. 54) refleja la orientación productivista de la agricultura mexicana, al tratarse de mercancías en las que el país presenta determinadas ventajas climáticas y laborales para su producción, como las frutas y hortalizas, además de la agroindustria avícola (tanto carne como huevo).

El maíz es el único grano cuya producción per cápita aumentó en este periodo, aunque su comportamiento ha sido errático, pues mientras en el periodo entre 1992 
Cuadro 2. Producción agropecuaria per cápita en México

\begin{tabular}{|c|c|c|c|c|c|}
\hline & 1980 & 1993 & 2000 & 2005 & Cambio 2005/1980 \\
\hline PIB agropecuario/hab (pesos de 1993) & 908.36 & 804.24 & 801.61 & 845.65 & $-6.9 \%$ \\
\hline Maíz (kg/hab) & 182.24 & 200.50 & 174.52 & 189.13 & $3.8 \%$ \\
\hline Frijol (kg/hab) & 14.44 & 14.65 & 8.83 & 8.00 & $-44.6 \%$ \\
\hline Trigo (kg/hab) & 41.01 & 39.63 & 34.72 & 29.16 & $-28.9 \%$ \\
\hline Arroz (kg/hab) & 6.56 & 3.18 & 3.49 & 2.81 & $-57.2 \%$ \\
\hline Leguminosas (kg/hab) & 19.72 & 17.65 & 12.23 & 14.11 & $-28.5 \%$ \\
\hline Frutas (kg/hab) & 112.19 & 115.11 & 132.35 & 144.18 & $28.5 \%$ \\
\hline Hortalizas (kg/hab) & 63.26 & 72.90 & 92.64 & 108.99 & $72.3 \%$ \\
\hline Leche (l/hab) & 103.41 & 83.58 & 93.86 & 95.56 & $-7.6 \%$ \\
\hline Carne bovina (kg/hab) & 15.69 & 13.90 & 14.00 & 15.08 & $-3.9 \%$ \\
\hline Carne porcina $(\mathrm{kg} / \mathrm{hab})$ & 18.42 & 9.09 & 10.24 & 10.68 & $-42.0 \%$ \\
\hline Carne de ave (kg/hab) & 5.88 & 11.70 & 18.14 & 23.60 & $301.3 \%$ \\
\hline Huevo (kg/hab) & 9.49 & 13.65 & 17.77 & 19.61 & $106.6 \%$ \\
\hline Miel (kg/hab) & 0.96 & 0.69 & 0.59 & 0.49 & $-48.9 \%$ \\
\hline
\end{tabular}

Elaborado con base en las siguientes fuentes: PIB: INEGI, Banco de Información Económica; proyecciones de población: Tercer Informe de Gobierno de Vicente Fox, 2003 y II Conteo de población y vivienda 2005; producción agrícola de 1994 a 2005 y pecuaria de 1980 a 2005: SIAP-Sagarpa; resto de producción: FAO, Faostat (consultado el 22 de mayo de 2007).

y 1995 creció mucho como resultado del impulso generado por el gobierno federal a través del programa Procampo, posteriormente vino un estancamiento que sólo empezó a recuperarse después del año 2000.

Resulta evidente, por lo tanto, que muchos agricultores y ganaderos han sido desplazados de sus explotaciones por productos importados que entran al país a un precio más bajo, sea que estos se importen de manera legal o ilegal ${ }^{4}$. Ahora bien, depender del extranjero para tener alimentos básicos es un hecho que vuelve vulnerable a México no sólo por razones externas (disponibilidad de alimentos en el mercado mundial), sino también internas (disponibilidad de recursos financieros para

\footnotetext{
${ }^{4}$ Guadalupe Rodríguez Gómez (1998: 42-44) dice que las importaciones de leche en polvo que se dieron desde finales de la década de 1980 hicieron de México el principal importador de este producto a nivel mundial, pero además muchas de estas importaciones provenían del mercado negro. Esto último lo hemos podido confirmar en entrevistas a productores y líderes de organizaciones ganaderas.
}

adquirirlos en cantidad suficiente y oportuna). Torres (2003: 33-34) señala que, aun cuando se logre un beneficio con la importación de alimentos baratos por un tiempo prolongado, a la larga se pierde porque se perjudica al sector agrícola. De esta manera, el país se transforma cada vez más en un importador neto, situación que vulnera la economía porque una variación en los precios internacionales de los alimentos tendrá repercusiones en el poder adquisitivo de los salarios, particularmente en aquellos sectores de la población de menores ingresos que gastan en alimentos una parte considerable de éstos.

\section{La balanza comercial agroalimentaria}

Ante los pronósticos de que México tendría superávit en su balanza comercial agroalimentaria, comprobamos lo contrario. Mientras que en 1991 el déficit del comercio ex- 
Gráfica 3. Balanza comercial agroalimentaria en México

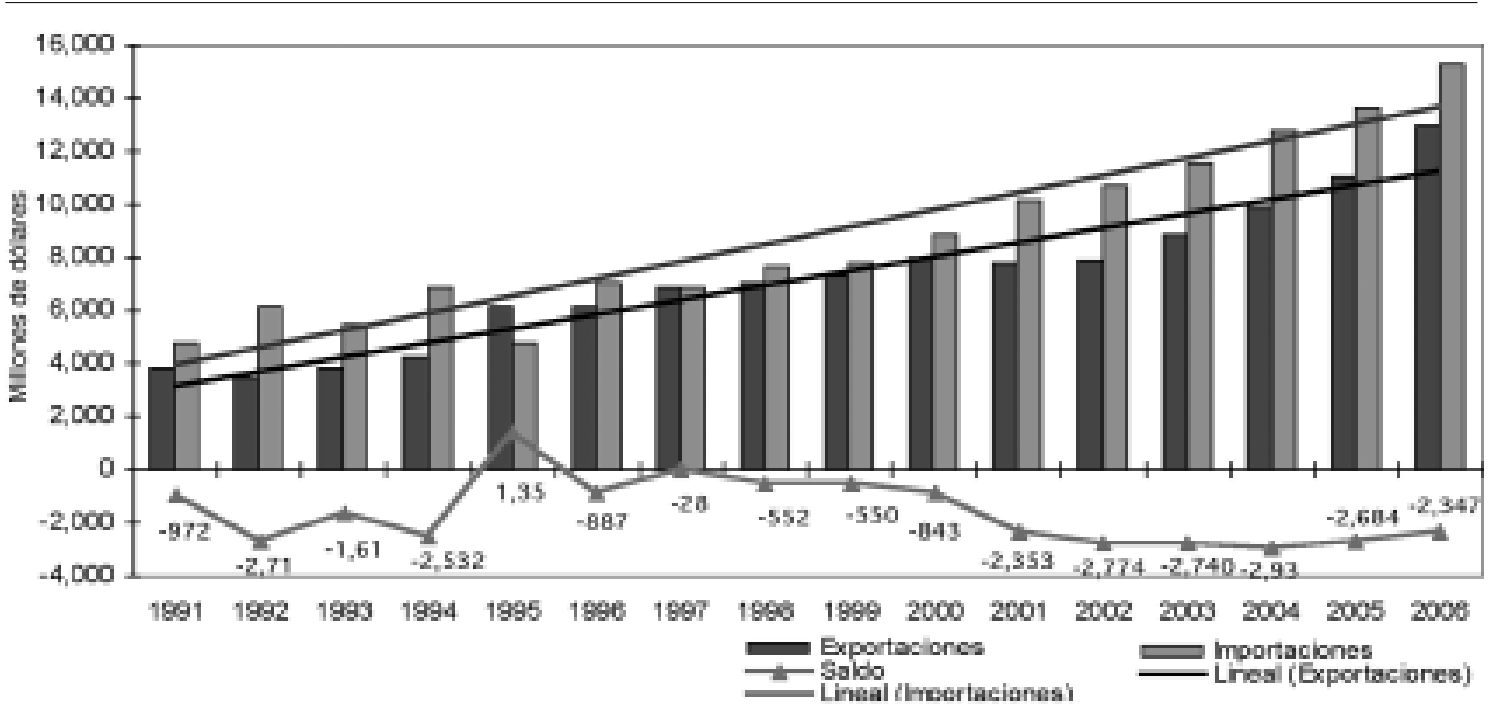

FUENTE: INEGI, Banco de Información Económica.

terior agroalimentario fue de 972 millones de dólares, en 1993 la cifra se había incrementado a más de 1600 millones. El deterioro más pronunciado se presentó a partir de la entrada en vigor del TLCAN en 1994, pues para el año 2004 el déficit fue de casi 3 mil millones de dólares, es decir, 81\% más que en 1993 (gráfica 3).

El problema del deterioro en la balanza comercial alimentaria se debe a que, aun cuando las exportaciones (principalmente de hortalizas y frutas frescas, pero también de productos industriales como la cerveza o el tequila) han crecido de manera importante, este aumento no ha sido suficiente para compensar el incremento de las importaciones, principalmente de granos, oleaginosas y algunos productos agroindustriales y la tendencia es que ello se intensifique (gráfica 3).

En el periodo de vigencia del TLCAN, el déficit promedio en el comercio exterior del sector agroalimentario ha representado casi 28\% del total nacional (en 2003 fue de 47\%), cuando en 1991 era de sólo 13.4\% ${ }^{5}$. Ello contrasta significativamente con la importancia de este sector en

\footnotetext{
${ }^{5}$ INEGI, Banco de Información Económica, op. cit.
}

la economía, a la que sólo contribuyó con menos de 10\% del PIB en 2006.

El problema más grave se presenta en la balanza comercial agropecuaria, es decir, la que se encuentra directamente relacionada con el campo. En ella todavía en 1991 el país exportaba más de lo que importaba, pero desde 1993 el deterioro de la balanza ha ido en aumento, de manera que en 2006, su déficit es $261 \%$ superior al existente en 1993. De hecho, México se ha visto obligado a erogar por concepto de compra de alimentos, durante el periodo del TLCAN, casi 20000 millones de dólares por encima del valor de sus exportaciones.

Según la FAO, cuando el valor de las importaciones de un país supera en $25 \%$ el valor de sus exportaciones totales existe una situación de riesgo de que éste no cuente con suficientes divisas para comprar alimentos (Mendoza, 2000, cit. en Torres y Aguilar, 2003: 99). Aunque México se mantiene lejos de este límite, ya que entre 1991 y 2006 el valor de este indicador fue de 5.3\%, entre 1992 y 1994 sí se superó, lo que nos habla de que en cualquier momento se puede caer en ese estado de vulnerabilidad económica y alimentaria. Además, en varios de los principales cultivos básicos es importante el porcentaje de importa- 


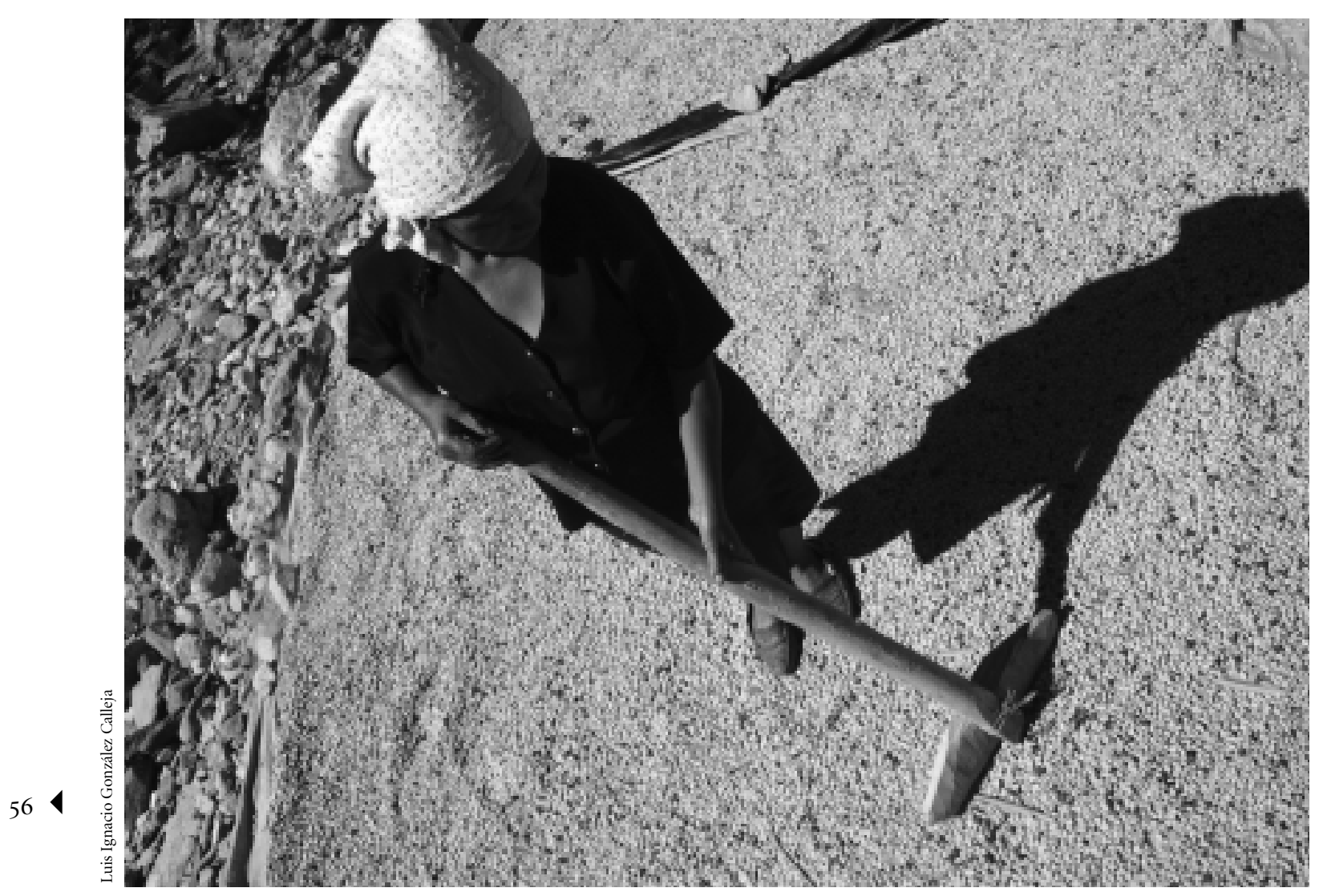

Los pequeños productores del café de exportación.

ciones respecto al consumo nacional aparente, respecto a lo cual resaltan en 2005 los casos del arroz (72\%) y el trigo (59\%), aunque también el maíz tiene un valor de $23 \%$ (aunque cabe señalar que en el caso del maíz blanco para consumo humano prácticamente toda la producción es nacional) y el frijol de 9\% (Fox, 2006: 405).

El hecho de que el país esté cada vez más lejos de conseguir una balanza comercial superavitaria en el sector alimenticio provoca que en la actualidad los demás sectores de la economía tengan que financiarlo. La fuga de divisas, por otra parte, ha resultado perjudicial para los productores nacionales y los trabajadores del campo, quienes ven limitadas sus oportunidades de vida. El descenso del empleo en la agricultura supera con mucho al que presenta el resto de la economía, como podrá verse más adelante.

\section{Concentración de las importaciones y exportaciones}

Un grave problema del comercio exterior mexicano en la actualidad es su creciente concentración tanto en términos geográficos, como de productos y empresas exportadoras. Respecto de lo primero, como señalan Torres y Aguilar (2003: 99-122), resulta preocupante la creciente concentración de las importaciones mexicanas de alimentos básicos como maíz, frijol, sorgo, trigo, carne de res y de puerco, y de las exportaciones de hortalizas y frutas frescas y secas a un solo país, Estados Unidos, no obstante que en el caso de la leche, la mantequilla, las grasas butílicas y los preparados alimenticios el país ha diversificado sus fuentes de abasto desde 1970 a la actualidad. Esta concentración y dependencia en el abasto 
Gráfica 4. Comercio exterior agroalimentario de México con Estados Unidos, 1989 y 2006

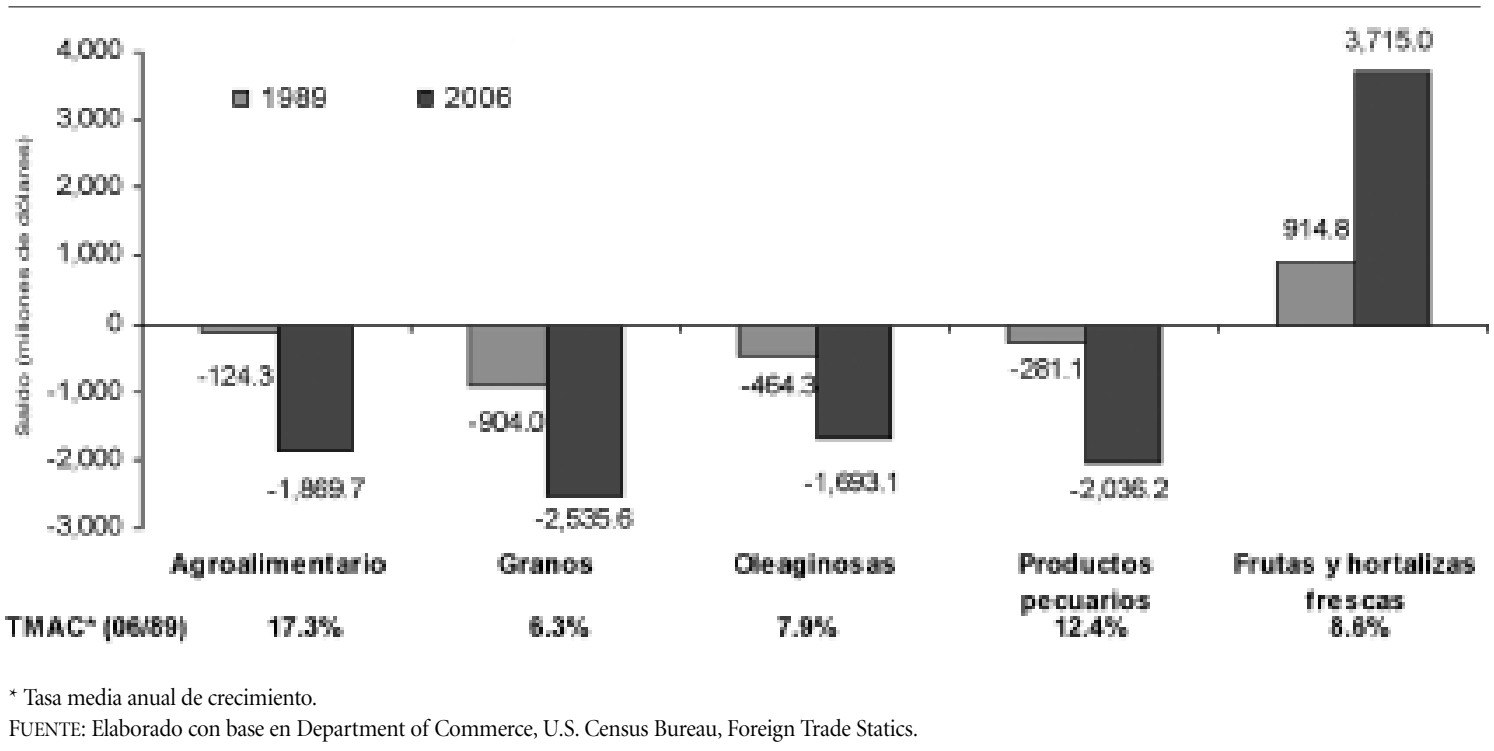

alimentario, concluyen estos autores, implica vulnerabilidad para México. Históricamente el gobierno estadounidense ha establecido lineamientos y sanciones en la venta de sus productos alimenticios en razón de sus intereses estratégicos y de su predominio económico y militar en el mundo. El caso más cercano lo tenemos con el embargo económico que este gobierno ha impuesto a $\mathrm{Cu}-$ ba desde la década de 1960, el cual viola las leyes internacionales de comercio y ha implicado un encarecimiento de las medicinas y de los alimentos que ha vulnerado severamente la salud y la nutrición de la población de la isla (Barry, 2000). La Comisión de Derechos Humanos y la Organización de Estados Americanos (OEA) han informado al gobierno de Estados Unidos sobre un incremento de las epidemias y de las enfermedades neurológicas en la isla por causa de esta política, sin que haya habido ningún cambio (Kirkpatrick, 1996).

La concentración en el comercio exterior agroalimentario que México tiene con Estados Unidos se agrava puesto que su déficit es creciente, debido a una tasa de incremento media anual de $17.3 \%$ entre 1989 y 2006; destacan, en particular, los rubros de productos básicos para la alimentación como granos, oleaginosas y productos pecuarios (gráfica 4).
En el comercio de frutas y hortalizas frescas, México es competitivo y tiene un saldo superavitario con Estados Unidos; sin embargo, este crecimiento de $8.6 \%$ entre 1989 y 2006, que es considerado un "logro" de la política gubernamental, se realiza en condiciones de alto riesgo para la agricultura y para los sectores económicos relacionados con ella. En primer lugar, porque se trata de exportaciones agrícolas que están sujetas a constantes vaivenes en los precios y en la demanda del mercado internacional y a regulaciones sanitarias cada vez más estrictas por parte de los países importadores. Los productos hortofrutícolas, por su sofisticación, implican costos crecientes para los productores, que llevan a disminuir su margen de utilidad, lo que se agrava por las barreras proteccionistas no arancelarias que aplican los países consumidores, como sucede con la ley contra el "bioterrorismo" de Estados Unidos. En segundo lugar, porque las exportaciones hortofrutícolas han cobrado una importancia creciente en el valor total exportado (entre 1994 y 2006 las frutas y hortalizas representaron 60\% del total de exportaciones agropecuarias 6 ) y cualquier variación

${ }^{6}$ INEGI, Banco de Información Económica, op. cit. 
tiene repercusiones sensibles en la balanza comercial agrícola y en el empleo directo - se trata de cultivos intensivos en mano de obra- e indirecto. En tercer lugar, porque a diferencia de países como Chile e Israel, que han tratado de diversificar sus exportaciones de frutas $y$ hortalizas en varios mercados y productos para disminuir los riesgos y ampliar oportunidades, México mantiene una creciente concentración de sus exportaciones a Estados Unidos, país al que dirigió $84 \%$ de éstas durante el periodo del TLCAN, con un máximo de $89.6 \%$ en 20057 . Además, México mantiene una marcada concentración en unos cuantos productos, pues durante el periodo de vigencia del TLCAN hasta 2006, cinco de ellos (jitomate, pimiento, pepino, cebolla y aguacate) representaron casi la mitad de las exportaciones hortofrutícolas (en 2006 estos productos significaron 53\% del total), destacando el jitomate $(21.4 \%)$ y el pimiento $(11.9 \%)^{8}$.

Por lo que toca al sector agroindustrial, las exportaciones también se concentran fuertemente en unos pocos productos. En el periodo de 1994 a 2006 la cerveza, el tequila y otras bebidas alcohólicas representaron $58 \%$ del total sectorial, desplazando a los productos alimenticios ${ }^{9}$. Así, la cerveza, que en el periodo de 1991 a 1993 representó $12.7 \%$ de las exportaciones agroindustriales, aumentó su participación a 31\% en el periodo de 1994 a 2006, mientras que el tequila pasó de 8.2 a 12.2\% entre ambos periodos y las bebidas alcohólicas se ubicaron en 14.4\% entre 1994 y 2006.

Finalmente, una característica que conlleva la concentración de las exportaciones alimenticias mexicanas en un número limitado de productos es que también son realizadas por pocas empresas. En el caso de la producción primaria, a pesar de que existen siete millones de

\footnotetext{
${ }^{7}$ Department of Commerce, U. S. Census Bureau, Foreign Trade Statics, Boureau of Commerce, Foreign Trade Statics, en <http://www. fas.usda.gov/ustrade/>, consultado el 28 de mayo de 2007; INEGI, $i b i$ dem.

${ }^{8}$ INEGI, ibid.

${ }^{9}$ Los principales grupos de productos agroindustriales alimenticios en el periodo de 1994 a 2006 fueron los productos de panadería, con una participación de 5.5\%, y los artículos de confitería sin cacao, con 5.4\%. SHCP, op. cit.; Banco de México, Estadísticas (<http://www.banxico. org.mx/tipo/estadisticas/index.html $>$, consultado entre el 15 y el 30 de mayo de 2007); Secretaría de Economía; INEGI.
}

unidades de producción, las que exportan constituyen una parte casi insignificante de ellas si se considera que en el grupo más dinámico, los hortofruticultores, sólo lo hacen alrededor de 20 mil productores (Schwentesius y Gómez, 1998: 177). Otros exportadores son los cafetaleros, pero muchos de ellos tienden a desaparecer toda vez que este producto enfrenta una grave crisis ocasionada por las fluctuaciones a la baja de los precios mundiales del café.

En cuanto a las empresas exportadoras en la industria de alimentos, bebidas y tabaco, éstas son sólo 1692 de las más de 32 mil que existen ${ }^{10}$, además de que $80 \%$ de las exportaciones son llevadas a cabo únicamente por 300 empresas, la mayoría de ellas de capital principalmente extranjero. Un ejemplo claro de lo anterior se observa en las industrias de cerveza y tequila, en las cuales la mayoría de las empresas exportadoras ya no son 100\% mexicanas. En el caso de la cerveza, el grupo Modelo, que controla más de $60 \%$ del mercado nacional y de las exportaciones de esta bebida, pertenece en 51\% a Anheuser-Busch. Igualmente, $30 \%$ de las acciones del grupo cervecero FEMSA son propiedad de Labatt Brewing Company Limited de Canadá. Adicionalmente, un porcentaje cada vez mayor de la materia prima para la cerveza, como cebada, malta y lúpulo, son importadas, lo que significa que las empresas productoras de cerveza en México prácticamente se convierten en "maquiladoras" más que en verdaderas productoras (Gómez y Schwentensius, 2003).

En el caso del tequila existe una situación similar ya que, si bien es cierto que la materia prima tiene que ser por fuerza mexicana debido a la denominación de origen, las grandes empresas tequileras son objeto de una creciente y cada vez más considerable inversión extranjera. Sauza, por ejemplo, pertenece en su totalidad al grupo estadounidense Fortune Brands; Herradura a Brown-Forman; Viuda de Romero a la francesa Pernod Ricard; Cazadores a Bacardí; Tequila Patrón a Caribbean Distillers Corporation, así como La Azteca y Sin Rival son en parte pro-

\footnotetext{
${ }^{10}$ Bancomext (Banco Nacional de Comercio Exterior), Bancomext Trade Directory of Mexico, 2007, en <http://www.buyinmexico.com.mx/ Bancomext/aplicaciones/businesscenter/mexicanExportersRes.jsp?id Sector=1>, consultado el 27 de mayo de 2007.
} 
piedad de Seagram's, y Don Julio de la inglesa Diageo (Macías y Valenzuela, 2007). Sólo Corralejo, Orendain y Tequila Cuervo son las únicas entre las principales compañías tequileras que en la actualidad son 100\% de capital mexicano, aunque Brown-Forman fue propietaria parcial de Orendain hasta 2007 y Diageo fue accionista de Cuervo hasta 2002 (Macías y Valenzuela, 2007).

Decir que las exportaciones de tequila y cerveza del país están creciendo esconde otra gran verdad, pues aunque son productos de México, en su mayoría ya no están en manos de mexicanos. Los propietarios los manejan de acuerdo con una estrategia que implica —en el caso de las bebidas alcohólicas - comercializar varios productos que proceden de diferentes países. Por lo anterior, advertimos una mayor vulnerabilidad de la economía debido a que los centros de decisión para responder a las demandas del mercado interno y a los requerimientos de inversión en importantes ramas del sector agroindustrial se definen en el exterior con una participación cada vez menor de los productores e industriales del país.

\section{Capacidad competitiva de los productores de granos: el caso del maíz}

La producción competitiva de alimentos ha sido un objetivo central de la política agrícola de los últimos años que vale la pena evaluar respecto al principal cultivo de México, que es el maíz. Éste tuvo su origen en el territorio que hoy ocupa México y posibilitó el desarrollo de la agricultura en la región de Mesoamérica. Desde entonces ha sido la base de la alimentación de la población y tiene gran importancia social y cultural, particularmente en las áreas de producción campesina e indígena.

En 2006 se sembraron 7.86 millones de hectáreas de maíz, que representaron $77 \%$ de la superficie agrícola sembrada con granos básicos, y se empleó alrededor de 2.88 millones de productores ${ }^{11}, 85 \%$ de los cuales lleva su

${ }^{11} \mathrm{Nadal}$ (2000a: 4) señala que en una superficie de 8.6 millones de hectáreas había 3.15 millones de productores de maíz. Si mantenemos la misma relación entre hectáreas sembradas y productores, para 7.86 producción en parcelas menores a cinco hectáreas (Moody y García León, 2007: 67).

Del total de la población empleada en el campo, que hasta el primer semestre de 2006 era de 6.16 millones de personas (Fox, 2006: 36), aproximadamente $47 \%$ produjo maíz (independientemente de que también hayan cultivado otros productos). En general, estos agricultores producen en tierras de temporal de baja calidad $(85.5 \%$ de la superficie sembrada con maíz entre 1996 y 2006 es de temporal [SIAP, 2007]), con poco acceso a los avances tecnológicos, el crédito y los canales de mercado en que pudieran vender su producto con buen margen de utilidad. Además, la mayoría no cuenta con bodegas para almacenar su producto, por lo que tienen que venderlo inmediatamente después de la cosecha, cuando los precios del mercado local suelen encontrarse en su nivel más bajo. Finalmente, dependen cada vez más de los recursos que obtienen en actividades distintas de la agricultura, a través de la migración (sobre todo internacional) y el cultivo de drogas.

Entre 1994 y 2006, mientras la superficie sembrada con maíz disminuyó $14.26 \%$, la producción creció en $20.44 \%$ (Fox, 2006: 395, 410; SIAP, 2007: 28). En el periodo de vigencia del TLCAN (de 1994 a 2006) la producción nacional ha abastecido $80.1 \%$ del consumo del país, cuando en el promedio de 1990 a 1993 el porcentaje de abastecimiento nacional era de 90.3\% (Fox, 2006: 405). Por lo tanto, aunque se ha incrementado la producción, ha sido en niveles muy por debajo de los que se requieren para cubrir las necesidades de consumo interno. Por ello, las importaciones aumentaron al pasar de 1.74 millones de toneladas anuales en promedio para el periodo $1980 \mathrm{a}$ 1988, a 5.04 millones de toneladas en el promedio del periodo 1994 a 2006 (Fox, 2006: 405). De hecho, la com-

millones de hectáreas corresponderían 2.88 millones de productores. Además, de acuerdo con Moody y García León (2007: 67), en 2006 existían alrededor de 2.5 millones de productores de maíz que sembraban en 6.5 millones de hectáreas de temporal (sin contar a los que siembran en tierras de riego). Finalmente, en un estudio realizado por el Sistema de Información Agrícola y Pecuaria (SIAP, 2007: 47) se menciona que en 2004 existían cerca de dos millones de productores de maíz. En todo caso, de acuerdo con nuestros cálculos casi 270000 productores de maíz abandonaron su actividad de 1994 a 2006. 
Gráfica 5. Rendimiento del maíz en países del TLCAN

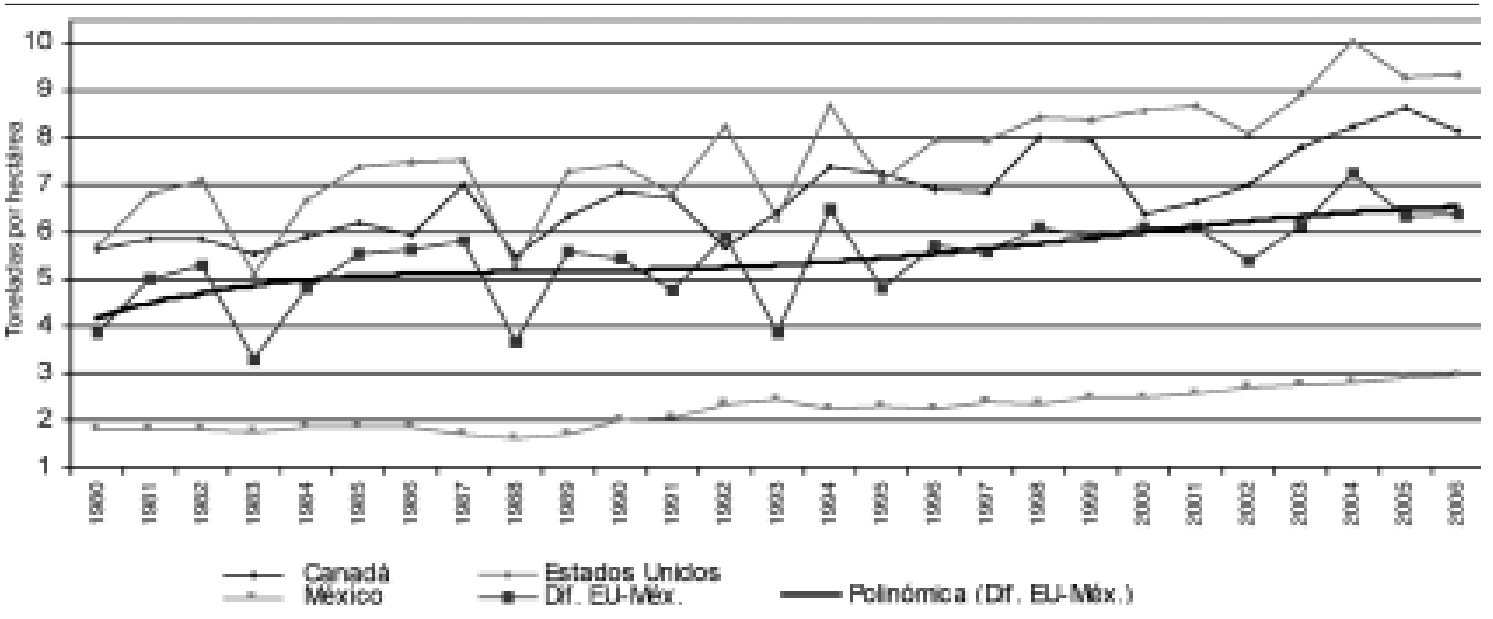

FUENTE: FAO, Faostat (<www.faostat.fao.org >, consultado el 29 de mayo de 2007).

pra de maíz en el exterior ha implicado la erogación de casi 8545 millones de dólares sólo entre 1994 y $2006^{12}$.

En cuanto a la productividad alcanzada en este grano con la apertura económica, los rendimientos se han incrementado de manera notable, al hacerlo en $62 \%$ en 2006 respecto a 1980 (Fox, 2006: 395, 41013). No obstante, las diferencias de productividad de Canadá y Estados Unidos con relación a México son notables e incluso, lejos de disminuir con la firma del TLCAN, muestran una clara tendencia a incrementarse (gráfica 5). México tuvo en 2006 un rendimiento promedio de 2.96 toneladas de maíz por hectárea, mientras que en Canadá fue de 8.18 y en Estados Unidos de 9.36 toneladas por hectárea ${ }^{14}$.

La situación futura de los productores de maíz en México es preocupante por varias razones:

1. Porque Estados Unidos es una potencia exportadora desde hace varias décadas. En 2005 produjo 39.7\% de este grano a nivel mundial, en tanto que México sólo

12 INEGI, Banco de Información Económica, op. cit.

${ }^{13}$ Véase también FAO, Faostat, en <www.faostat.fao.org > consultado el 29 de mayo de 2007.

${ }^{14}$ FAO, Faostat, op. cit. produjo $2.5 \% 0^{15}$ y cada vez es menos capaz de abastecer su mercado interno.

2. Porque hay grandes diferencias en costos y productividad entre México y sus principales socios comerciales como para poder competir. Además, México ha seguido la misma tónica que otros países en desarrollo en cuanto a reducir los subsidios otorgados a los productores de maíz y, aunque lo ha hecho en un menor porcentaje que la mayoría de los demás miembros de la OCDE, de todas formas las asimetrías no sólo se mantienen sino que continúan creciendo. Agréguese a esto que los costos de producción del maíz blanco en México son 25\% más altos que los del maíz amarillo importado de Estados Unidos (Nadal, 2000b: 16); sin embargo, en el mercado mexicano los precios internos se han alineado a la variedad amarilla importada (Nadal, 2000b: 62), aunque en sentido estricto no se trata de productos sustitutos ya que el maíz amarillo normalmente es utilizado como alimento para los animales, para la industria del jarabe y, recientemente, para la producción de etanol, mientras que el blanco resulta más

\footnotetext{
${ }^{15}$ FAO, Faostat, op. cit.
} 
adecuado para el consumo humano (Nadal, 2000b: 16; Henriques y Patel, 2004).

3. Porque la liberalización del mercado mexicano del maíz se ha hecho sin pensar en las asimetrías anteriormente señaladas. México acordó en el TLCAN que de 1994 a 2007 podría aplicar un arancel a las importaciones de maíz y frijol de Estados Unidos que sobrepasaran determinadas cuotas de importación. Esta medida reconocía la desigualdad tecnológica y económica de los productores de las dos naciones y buscaba dar a los agricultores mexicanos la oportunidad de "reconvertirse" y ser competitivos. Hasta el presente el gobierno mexicano no ha aplicado ningún arancel a las importaciones que sobrepasaron las cuotas de importación en los dos cultivos mencionados y ha justificado su proceder aduciendo presiones inflacionarias, caídas de la producción nacional y exceso de demanda respecto a la oferta; ni ha recurrido a salvaguardas o medidas de emergencia para defender a sus productores (Nadal, 2000b; Nadal y Wise, 2004; SIAP, 2007). Entre 1994 y 2001 el arancel que el gobierno mexicano dejó de cobrar a las importaciones que sobrepasaron la cuota acordada fue de 2800 millones de dólares en el caso del maíz y de 77 millones de dólares en el del frijol (Gómez y Schwentesius, 2003).

El efecto pernicioso de esta medida no estriba en los aranceles que se dejaron de percibir, sino en la caída del precio real de estos cultivos en el mercado nacional a consecuencia de las importaciones más baratas de Estados Unidos. El precio real del grano pagado al productor cayó 58\% entre 1993 y $2006^{16}$, por lo que los productores mexicanos operan en condiciones de desigualdad, con lo que quedan limitadas sus oportunidades en el mercado interno.

\footnotetext{
${ }^{16}$ OCDE, Databases 2005; SIAP, 2007. Aunque cabe señalar que el precio en enero de 2007 ha tenido un incremento importante debido el crecimiento de la demanda del grano por parte de Estados Unidos para producir etanol (Secretaría de Agricultura, Ganadería, Pesca y Alimentación, Servicio de Información Agroalimentaria y Pesquera [SIAPSagarpa], Anuarios estadísticos, en <http://www.siap.gob.mx/ >, consultado entre el 10 y el 31 de mayo de 2007).
}

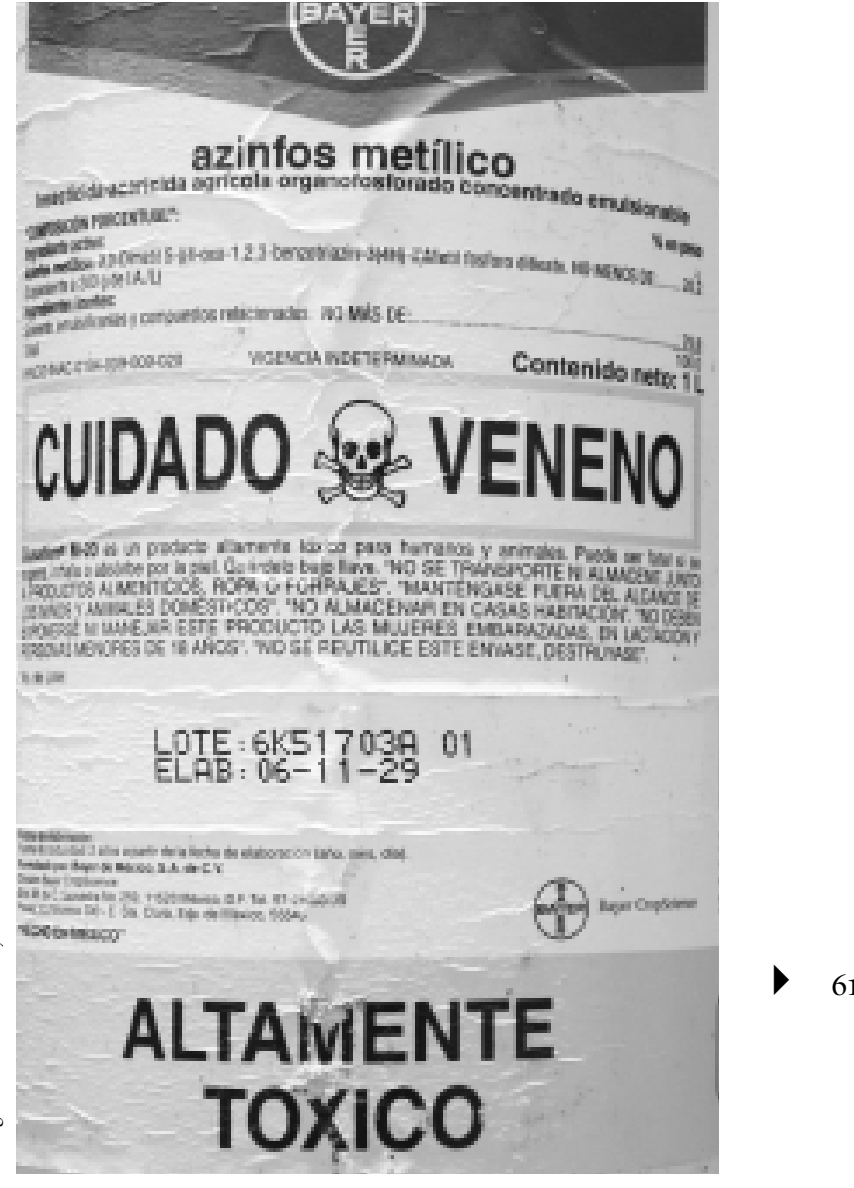

El drama de los pesticidas.

\section{LA VULNERABILIDADY LAS CONDICIONES AMBIENTALES}

Con base en estudios recientes sobre la relación entre sustentabilidad y apertura comercial, abordaremos dos problemáticas relevantes para la vulnerabilidad agroalimentaria: el quebranto de la riqueza fitogenética del maíz y la degradación ambiental que observamos en las regiones que producen los cultivos más dinámicos del sector exportador, es decir, frutas y hortalizas. A estas dos problemáticas agregaremos la del cambio climático global, que ha sido poco estudiada pero sobre la que se avizoran implicaciones directas y severas en la vulnerabilidad agroalimentaria de México. 


\section{Quebranto a la diversidad genética}

El caso del maíz es notable por su diversidad genética y porque los depósitos de su germoplasma en México han contribuido al crecimiento de la producción mundial (Nadal, 2000a: 3). México cuenta con 60 complejos raciales de maíz y miles de sub-razas y variedades locales (Álvarez-Buya, 2004: 181). Su cuidado ha estado en manos de pequeños agricultores que cada año seleccionan las semillas que mejor se adaptan a las condiciones físicas y climáticas de sus tierras, lo que ha permitido durante varias centurias la diferenciación y conservación de la riqueza genética que ha logrado el maíz en los ecosistemas de México. Ésta, sin embargo, se ha visto amenazada por diversos factores, entre los que se encuentran la introducción de semillas híbridas, la presencia de semillas transgénicas en áreas de mayor diversidad genética y la disminución física de los pequeños productores.

En primer lugar, las variedades híbridas, que también se llaman "mejoradas", sustituyen a las autóctonas. Éstas, si bien permiten un incremento de la producción agríco-

la, constituyen un número muy reducido comparado con las variedades tradicionales, las cuales se dejan de sembrar. La pérdida de estas últimas reduce las oportunidades para el mejoramiento genético de los cultivos, los cuales deben revigorizarse constantemente para contrarrestar los efectos de los insectos, para dotarlos de nuevas características con tolerancia a enfermedades, sequías o cambios en las condiciones del suelo, como salinidad o acidez (FAO, 1993). En este sentido, la mayor productividad alcanzada con un número reducido de variedades es también fuente de vulnerabilidad, ya que la diversidad permite mayores oportunidades para la adaptación a los cultivos. El resguardo de semillas en bancos de germoplasma (que pueden perderse o destruirse y estar sujetos a manejo político de parte de quienes los mantienen) nunca será igual a mantener las variedades de los cultivos in situ; es decir, en condiciones naturales donde deben responder a las situaciones cambiantes del ambiente.

Ahora bien, las variedades híbridas requieren de la aplicación más intensiva de energía fósil (combustibles y fertilizantes), de insumos externos como herbicidas e insecticidas y de riego. Las semillas, como los insumos, deben comprarse año con año al selecto y reducido grupo de empresas transnacionales. En contraposición con las variedades criollas, las híbridas son menos adaptables a la diversidad y a los cambios de las condiciones agroclimáticas; además, por la utilización de agroquímicos que contaminan y degradan el agua y el suelo, constituyen un riesgo para la salud humana y los agrosistemas (Altieri, 1990). Recientemente la propagación del uso de estas semillas ha sido alentada por el programa gubernamental "kilo por kilo", desarrollado en las áreas de agricultura marginal, y que consiste en el intercambio de un kilo de semillas tradicionales o criollas por uno de semillas híbridas.

En segundo lugar, la introducción de semillas transgénicas en la producción de alimentos es una intervención más profunda en la naturaleza que la masiva adopción de semillas híbridas, ya que tienen efectos más severos e impredecibles sobre la diversidad genética de los cultivos. Esta diversidad comprende a las razas tradicionalmente cultivadas, pero también a sus progenitores silvestres en las áreas donde se originan y diversifican los cultivos, como es el caso del maíz en México. Entre todas estas variedades y razas, incluidos los cultivos industriales, existe una "conectividad genética", la cual es un factor determinante de la evolución histórica de los cultivos y de los agrosistemas del mundo en los que se desarrollan (Quist y Chapela, 2001: 541). Mantener los centros de biodiversidad en las regiones del mundo es un recurso agrícola fundamental, ya que se puede recurrir a ellos para encontrar genes que permitan enfrentar problemas de plagas y de enfermedades de los cultivos o simplemente para mejorarlos. En este sentido, la diversidad de los cultivos "es considerada esencial para la seguridad alimentaria mundial" (ibid., el énfasis es nuestro) ${ }^{17}$.

Por lo anterior, resulta grave la presencia de transgénicos en el estado de Oaxaca, el área de origen y diversi-

\footnotetext{
17 Un ejemplo histórico reciente de las oportunidades que ofrece mantener la diversidad genética en las áreas de origen y diversificación de los cultivos es el que se presentó con la peste virulenta que afectó de manera importante a una sexta parte de la producción del maíz en Estados Unidos. Los fitogenetistas de este país encontraron dos variedades de maíz silvestre de México, que les permitieron conferir al maíz doméstico resistencia a dicha enfermedad (Lean, Hinrichsen y Markham, 1990).
} 
ficación del maíz, que es el cereal más producido en México, pero también en el mundo. No es gratuita la propuesta de que la diversidad genética del maíz, que los campesinos de Oaxaca y de otras regiones de México han desarrollado y preservado por generaciones durante varias centurias, sea considerada un patrimonio de la humanidad y de que el gobierno de México y la comunidad internacional asuman su responsabilidad en esta tarea a partir de los tratados internacionales, como el Protocolo de Cartagena que deriva del Convenio sobre la Diversidad Biológica (Wise, 2006).

En México, a pesar de que en 1998 se prohibió sembrar semillas transgénicas, en 2001 se detectó su presencia en los campos de Oaxaca y de otros lugares de México (Quist y Chapela, 2001; Vaughan, 2003: 76; Nadal y Wise, 2004: 14). Las variedades que se encontraron fueron el maíz Bt y la variedad tolerante a componentes de herbicidas de amplio espectro, las cuales son las variedades transgénicas que más se siembran en Estados Unidos y se exportan a México (Nadal y Wise, 2004: 14) ${ }^{18}$. Según Julien Berthaud y Paul Gepts (2004) existe un consenso sobre "la presencia de secuencias transgénicas en razas criollas de maíz en el campo mexicano". Ante esas circunstancias, resulta urgente evaluar los riesgos que para la biodiversidad en México pueden implicar estos cultivos, pues aún cuando Goodman y García Barrios (2004) establezcan que la mayoría de los transgenes del maíz difícilmente representarán mayor amenaza para las variedades tradicionales locales, otros investigadores han documentado riesgos de diversa índole ${ }^{19}$.

\footnotetext{
${ }^{18}$ A la primera se le insertó el gen de la bacteria Bacillus thuringiensis, por medio del cual la planta de maíz produce una proteína tóxica, la prototoxina $\mathrm{Bt}$, que le confiere características insecticidas para controlar el llamado "barrenador del maíz"; la segunda, en cambio, vuelve a las plantas de maíz resistentes a la aplicación de herbicidas cuyo componente principal es el glufosinato. Estos herbicidas se aplican durante la mayor parte del ciclo productivo para combatir la maleza que compite con la planta de maíz por los nutrientes, la luz y el agua.

${ }^{19}$ En el caso del maíz Bt, estos son: 1) la posibilidad de introgresión (que los genes entren y persistan) de las variedades transgénicas a las criollas y a los parientes silvestres (Álvarez-Buya, 2004: 182), con todo y que el tamaño de la región que pudiera ser afectada por la reducción en su diversidad genética depende de la ventaja selectiva del transgén seleccionado, además de que está en proporción inversa al nivel de recombinación genética del cultivo, siendo que el maíz presenta altos índices de recombinación (Berthaud y Gepts, 2004); 2) como la toxina
}

En 2005 se aprobó la Ley de Bioseguridad y aunque esta todavía no se ha implementado, deja muchas dudas respecto a que realmente proteja la biodiversidad de los maíces que existen en México, además de que todavía no se establecen parámetros claros para definir responsabilidades en caso de daños a los ecosistemas o a la salud pública. La presencia de transgénicos es una realidad progresiva que ocurre en otros cultivos, ya que de acuerdo con Greenpeace México (2007), muestreos oficiales realizados en la frontera entre agosto y octubre de 2006 identificaron la contaminación con transgénicos en 47 de las 51 muestras tomadas de los cargamentos de arroz importado.

Chapela (2005) señala que el impacto de los transgénicos "no se restringe al momento y lugar en que se les produce, sino que puede propagarse a través de las propiedades reproductivas de los organismos que las sufren"; aclara que "no sabemos lo suficiente para predecir la más mínima consecuencia de la intervención transgénica. No existe evidencia suficiente por la simple razón de que no se ha puesto suficiente atención a los problemas obvios y esperables de la manipulación genética de la naturaleza viva". Con base en estudios de la Fundación Nacional de la Ciencia de Estados Unidos en los que Chapela

\footnotetext{
transgénica se activa de manera inmediata, a diferencia de la natural, que lo hace sólo cuando es combinada con los ácidos estomacales de los insectos, puede atacar a un mayor número de insectos y organismos del suelo, incluso a aquellos que generan beneficios importantes para la fertilidad del mismo (Rifkin, 1999: 89); 3) además, la toxina transgénica sigue siendo tóxica en el suelo el triple de tiempo que la natural, de manera que es mucho más letal (Rifkin, 1999: 89); 4) el uso extendido de cultivos con Bt puede ocasionar que los insectos desarrollen resistencia, de manera que hasta la Bt natural se volvería inútil como biopesticida cuando actualmente es uno de los instrumentos naturales más importantes para el control de plagas; 5) siempre está latente la posibilidad de que mientras se maten algunos virus, las combinaciones genéticas puedan dar lugar a nuevos virus.

Por lo que respecta a las plantas transgénicas resistentes a herbicidas, el riesgo es que se incremente el uso de éstos para controlar la maleza, ya que los agricultores tendrán menos miedo de que ello dañe sus cosechas (Rifkin, 1999: 89). Igualmente, las malezas pueden desarrollar resistencia y con ello fomentar la producción de agroquímicos cada vez más agresivos contra el medio ambiente, además de que existe el riesgo de que las plantas transgénicas, cuyas características las hace tener ventajas competitivas respecto a las variedades autóctonas, se conviertan en maleza, sobre todo si emigran de los hábitat para los que fueron creadas; incluso, que la polinización cruzada haga resistentes a las malezas ya existentes.
} 


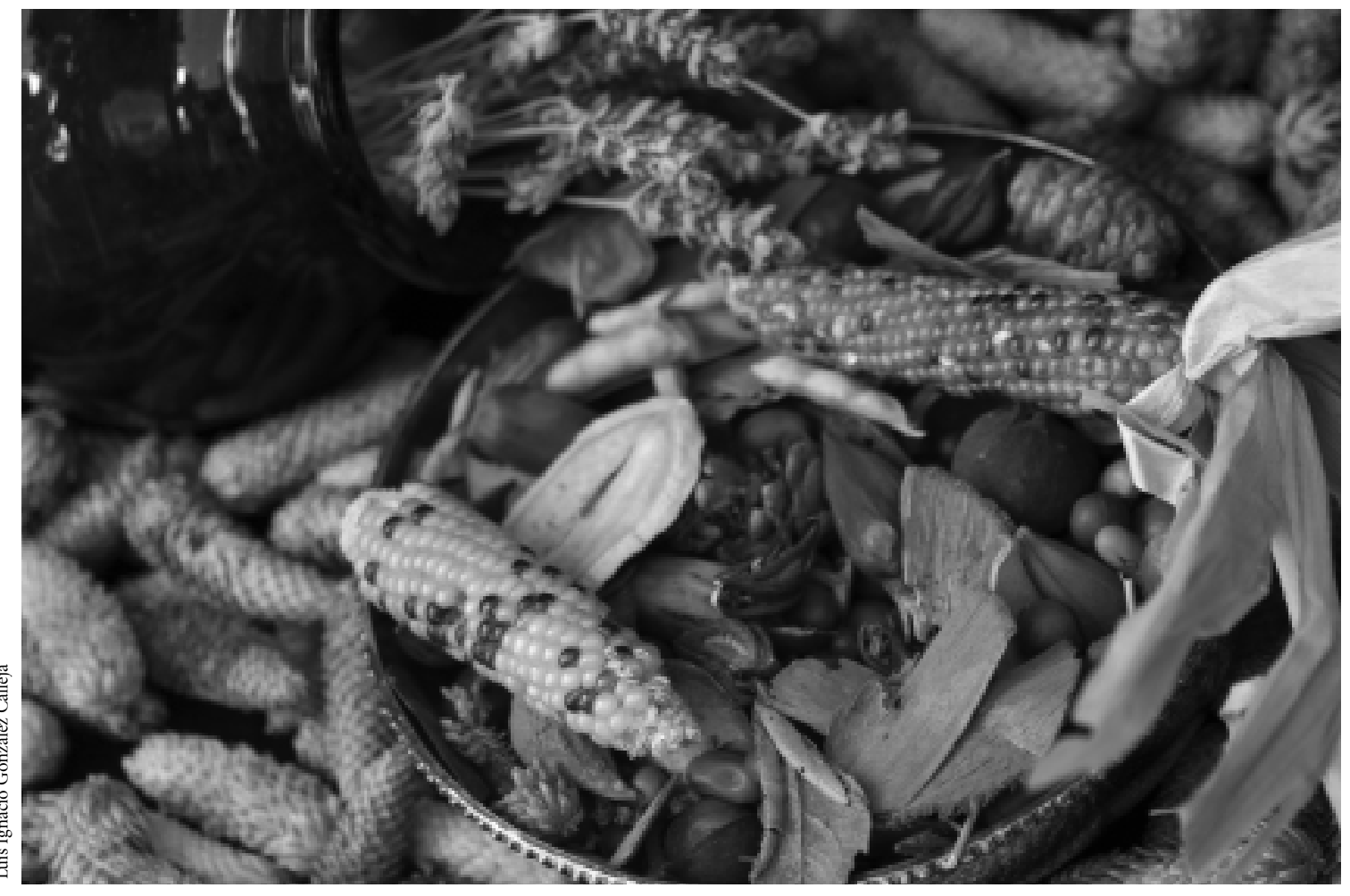

Variedades de maíz.

participó, comenta: "Aun en los países e instituciones más ilustradas y financieramente acomodadas [...] no existe ni la capacidad física, ni los recursos intelectuales, ni el interés institucional o la decisión política que serían necesarios para establecer los riesgos reales de los transgénicos, ni las medidas que serían necesarias para detectar la actualización de tales riesgos" (ibid.)

Por ahora, la mayor la vulnerabilidad que enfrenta la riqueza genética del maíz se debe a la disminución de los pequeños productores de grano en las áreas de agricultura tradicional. Ellos son quienes tienen el conocimiento para seleccionar las semillas, mantener in situ la biodiversidad y permitir su evolución. Nadal (2000a) y Nadal y Wise (2004) señalan que la disminución del precio real del maíz que se presentó hasta antes de 2006 llevó a buscar alternativas de ingresos y empleo fuera de la actividad agrícola, por lo que se ha abandonado el cultivo. Además, los procesos de urbanización y los cambios cultura- les que ello trae consigo hacen que se pierda la tradición de cultivar maíz para autoconsumo y crezca, aún en las áreas rurales, la predilección por comprar las tortillas.

Por otro lado, Vaughan (2003) señala que otra estrategia de los productores tradicionales de maíz para la disminución del valor real de grano ha sido ampliar la superficie de siembra en áreas marginales, donde se practica el cultivo de roza y quema. Este sistema de producción agrícola lleva no sólo a talar los árboles de los bosques y selvas para plantar maíz, sino que además origina incendios que terminan con grandes extensiones de recursos bióticos. México es uno de los principales centros de megadiversidad del planeta donde reside " $10 \%$ de todas las especies conocidas, de las cuales 30 a 50\% son endémicas" (Vaughan, 2003: 74).

El riesgo que implica para la salud humana la producción de alimentos con variedades transgénicas es materia de debate debido a que todavía no se ha hecho la su- 
ficiente investigación que permita evaluar con seguridad dicho impacto (Nadal y Wise, 2004; Vaughan, 2003). Sin embargo, un trabajo reciente prueba que existen fallas fundamentales tanto en las evaluaciones que practican las compañías biotecnológicas, como en las bases de información en que se fundamentan las regulaciones del gobierno de Estados Unidos, que estableció que los alimentos de origen transgénico son seguros para la salud humana (Freese y Schubert, 2004).

Existen evidencias de que problemas de alergias pueden asociarse al consumo de transgénicos, puesto que muchos de los genes utilizados provienen de plantas, animales y microorganismos que nunca antes habían sido utilizados para el consumo del hombre (Rifkin, 1999: 107) ${ }^{20}$. Este riesgo por sí mismo representa un problema de salud pública, por lo que ha llevado a regular la producción y el comercio de alimentos producidos con semillas transgénicas en Europa y Asia.

\section{Degradación ambiental de los cultivos de exportación}

Por lo que toca a la producción de cultivos en los que México tiene ventajas comparativas, como las frutas y hortalizas, éstos requieren de un uso intensivo e insustentable de recursos naturales como la tierra y el agua. González (2004) resalta cuatro problemas de degradación ambiental que caracterizan a la producción intensiva de monocultivos hortofrutícolas: la degradación de los suelos al no hacer una rotación de cultivos que permita al suelo recuperar su fertilidad; la contaminación y el abatimiento de los mantos freáticos, particularmente en áreas semidesérticas, donde el agua es escasa; los problemas de plagas y enfermedades que generan estos monocultivos y que a la postre llevan a abandonar las regiones productoras por incosteables y a buscar otras, donde después de cinco u ocho años vuelve a aparecer el mismo proble-

${ }^{20}$ Una explicación más amplia de esto y las referencias científicas pueden verse en "Ecologistas en acción", en: <http://www.ecologistasen accion.org/accion/biotecnologia/maiz.htm $>$, consultado el 20 de septiembre de 2004. ma; y, finalmente, el uso intensivo de agroquímicos que contaminan y deterioran los agrosistemas, pero también afectan la salud de los trabajadores y de las poblaciones que habitan cerca de los campos de producción.

Cada vez se documenta con mayor detalle cómo estos problemas de degradación ambiental se presentan en las regiones donde se producen intensivamente frutas y hortalizas para el mercado de exportación, lo que las convierte en lo que Macías (2003) llama zonas de coyuntura agrícola. En ellas los cultivos se desarrollan por un tiempo y cuando las empresas advierten que los problemas de degradación ambiental se vuelven críticos y demandan mayor inversión o conducen a una disminución de la productividad reducen sensiblemente su producción en el área o la abandonan para iniciar un nuevo ciclo en otra región "virgen", donde aún no se hayan sembrado hortalizas en gran magnitud e intensidad. Esta agricultura de coyuntura la encontramos en Autlán, Jalisco (González, 1994); el valle de Arista en San Luis Potosí (Maisterrena y Mora, 2000); en valles de Tierra Caliente, Guerrero (Bustamante, 1996); en el valle de San Quintín, Baja California (Cook y Amon, 1989); en el valle de Apatzingán, Michoacán (Agustín et al., 1994; Stanford, 1994); en el valle de Zamora, Michoacán (Sefoo, 1995); en Hermosillo, Sonora (Moreno, 1997), y recientemente en el valle de Sayula, Jalisco (Macías, 2006).

\section{El cambio climático}

Finalmente, uno de los más grandes riesgos para el futuro de la agricultura, principalmente la de temporal, que es la que más depende de las condiciones del medio ambiente local y que generalmente es llevada a cabo por pequeños productores, es el cambio climático global producto de la industrialización. Aunque investigadores como Robert Mendelsohn et al. $(1994,2000)$ han venido insistiendo en que este fenómeno puede traer beneficios a la agricultura en países polares e incluso pequeños beneficios en países de clima templado, la realidad es que para la mayoría de los países en desarrollo, tropicales y subtropicales, existen altos riesgos de que sus sistemas agropecuarios y forestales se vean muy afectados en los 
próximos años con una importante reducción en el rendimiento de sus cultivos, decremento significativo en la disponibilidad de agua, aumento de enfermedades, así como de riesgos por inundaciones (IPCC, 2001; Brathwaite, 2004).

Las consecuencias mundiales del cambio climático son reveladoras. Según el informe Cambio climático y vulnerabilidad de la agricultura, elaborado en 2002 por el Instituto Internacional para Sistemas de Análisis Integrados (IIASA), fenómenos como la desertificación, la erosión de tierras cultivables, la salinificación de acuíferos y la escasez de agua incrementarán el número de habitantes del planeta que presenten problemas de acceso a los alimentos (Fischer et al., 2002). Según este informe, sólo en 1998 las pérdidas económicas en los países subdesarrollados debida a sequías, huracanes, inundaciones, olas de calor o precipitaciones inestables superaron los 42 billones de euros, y se calcula que para 2080, exclusivamente por los efectos del cambio climático, se incrementará en $22 \%$ el número de personas en riesgo de padecer desnutrición (Fischer et al., 2002: 5, 113).

México es especialmente vulnerable al cambio climático global pues es precisamente un país con clima tropical en la mayor parte de su superficie, mismo que potencialmente se extendería a todo el territorio nacional como resultado de este fenómeno (Fischer et al., 2002: 40-41). De hecho, si llegara a duplicarse la concentración de bióxido de carbono $\left(\mathrm{CO}_{2}\right)$ con relación a los niveles preindustriales - lo que se calcula puede suceder alrededor del año 2025 (Schelling, 1993)—, esto traería graves consecuencias al país, pues 30\% de su territorio es de zonas áridas y semiáridas, además de que los bosques y selvas cubren $28 \%$ de la superficie total y alrededor de $80 \%$ de los suelos presenta cierto grado de erosión, principalmente por la deforestación de terrenos con pendientes pronunciadas (Semarnap, 1998: 13). En estas circunstancias, al duplicarse la concentración de $\mathrm{CO}_{2}$ se generarían procesos de desertificación, deforestación, erosión y pérdida de biodiversidad, de manera que las zonas en riesgo potencial severo y extremo por erosión hídrica podrían pasar del actual $57 \%$ a $70 \%$, además de que $48 \%$ de la superficie, principalmente en el norte del país, resultaría propensa a la desertificación y sequía meteorológica, mientras que los recursos hídricos serían particularmente vulnerables en las cuencas del Pánuco, del Lerma-ChapalaSantiago y en la península de Baja California (Gay, s.f.).

En el plano agrícola, de acuerdo con un estudio realizado por E. Flores et al. (mencionado por Conde et al., 2004), existe una gran vulnerabilidad en la producción de maíz de temporal en México ante una duplicación del $\mathrm{CO}_{2}$, pues ello ocasionaría la disminución de la superficie apta, así como una reducción importante en los rendimientos derivada de los considerables decrementos en las lluvias de verano. Esto sucedería especialmente en zonas de alta producción como Jalisco, Michoacán, Guerrero, Oaxaca, Tabasco y la península de Yucatán (Conde et al., 2004: 231-232)21. De hecho, la superficie no apta para siembra de maíz de temporal se incrementaría del actual 59.6\% a 75\% (Gay, s.f.).

La degradación ambiental y la pérdida de biodiversidad son manifestaciones de una agricultura insustentable que, aunadas a los efectos perniciosos del cambio climático, limitan las oportunidades de producir alimentos en el mediano y largo plazo y vuelven más vulnerable la sociedad nacional. En el corto plazo, lo que está en riesgo es el acceso de la población a los alimentos, el cual está mediado por condiciones socioeconómicas.

\section{LA VULNERABILIDADY LAS CONDICIONES SOCIALES}

El acceso físico y económico a una alimentación nutritiva, suficiente y saludable de todos los sectores de la población mexicana y su vinculación con la política agrícola serán analizadas de acuerdo con cuatro criterios: la producción de alimentos agrícolas baratos para la población, el empleo agrícola, el nivel de nutrición de la población y los índices de pobreza. Estos dos últimos muestran una realidad que no sólo es atribuible a la política agrícola, sino a la política económica en general.

\footnotetext{
${ }^{21}$ En el caso del Estado de México, potencialmente habría un incremento en los rendimientos, posiblemente asociado al aumento de la temperatura mínima que reduciría los daños por heladas (Conde et al., 2004: 231-232).
} 
Gráfica 6. Incremento en el precio de productos (diciembre de 1993 a abril de 2007)

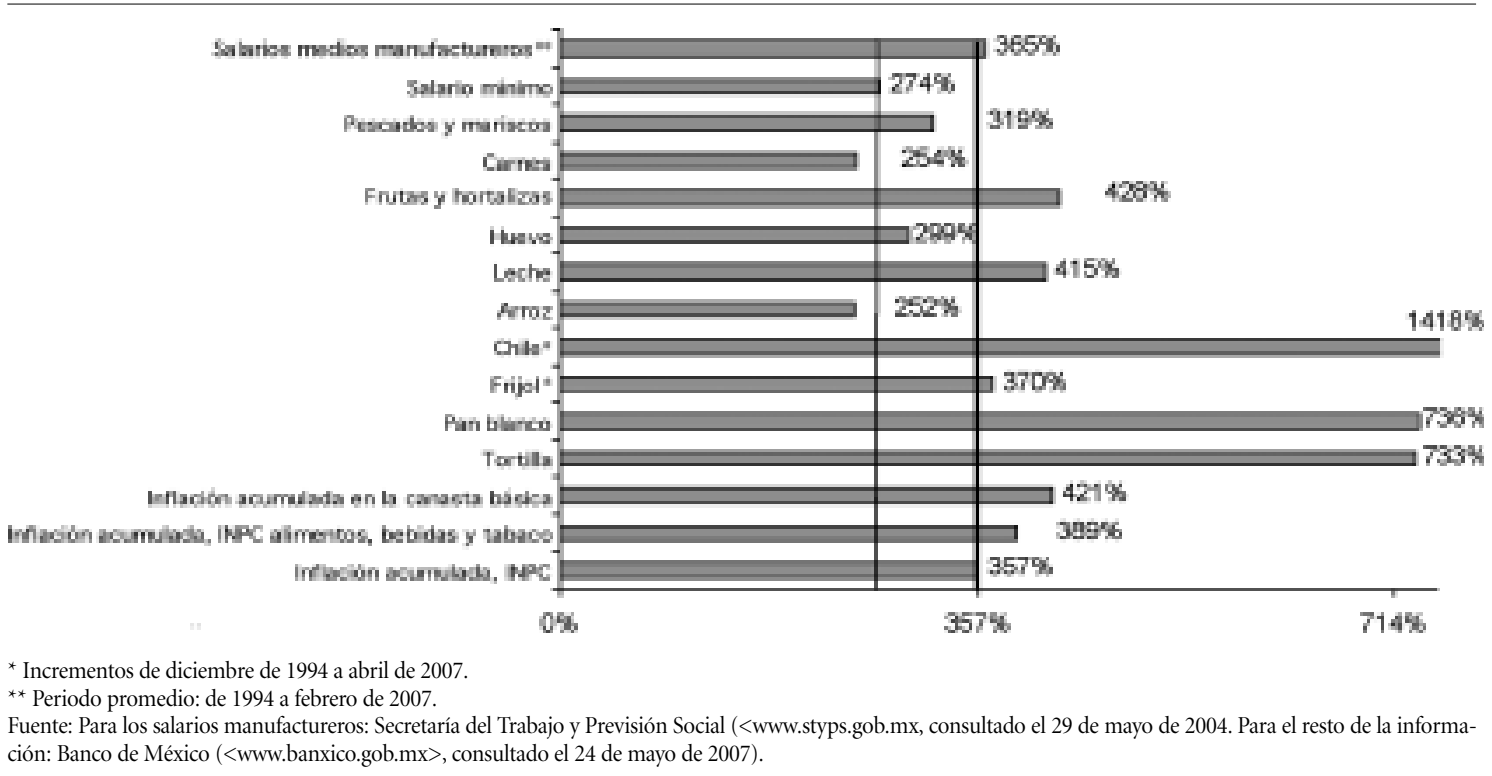

\section{Encarecimiento de los alimentos}

Una de las razones esgrimidas por el gobierno federal para promover la apertura comercial a fines de la década de 1980 era que con ella los precios en el mercado nacional forzosamente debían equipararse a los internacionales gracias a la libre competencia entre ambos, por lo que se daría una disminución significativa de los precios relativos internos. En el sector agropecuario se dijo exactamente lo mismo. Sin embargo, el resultado ha sido contrario a lo esperado, pues la inflación en el sector alimenticio es de $389 \%$ en lo que va de vigencia del TLCAN (hasta abril de 2007), en tanto que el incremento en el índice nacional de precios al consumidor (INPC) en ese periodo fue de $357 \%$ (gráfica 6).

Se podría argumentar que tal incremento incluye todos los alimentos, hasta los de lujo, bebidas alcohólicas y derivados del tabaco. Por lo mismo, consideramos necesario presentar la inflación acumulada de la canasta básica en el mismo periodo, que tiene un crecimiento de $421 \%$, mayor que el INPC. Lo anterior es todavía más delicado si se observa el comportamiento de los precios en los principales alimentos de los mexicanos, de los que supuestamente la apertura comercial iba a permitir su disminución relativa.

Veamos primero el caso del maíz. Mientras que los precios reales pagados al productor son negativos durante el TLCAN, en el principal producto derivado en que el consumidor mexicano consume maíz, es decir, la tortilla, el incremento en su precio ha sido, en el periodo de diciembre de 1993 a abril de 2007, de nada menos que $733 \%$, es decir, 376 puntos porcentuales más que la inflación. Es cierto que esto se debe en parte a que el gobierno ha ido eliminando el subsidio que se otorgaba a su consumo, pero para el consumidor la realidad es que uno de sus principales alimentos cuesta, en términos reales, mucho más que hace trece años, además de ser un producto que difícilmente puede sustituirse por otro, sobre todo si vemos que uno de los productos potencialmente equivalentes, el pan blanco, también ha aumentado $736 \%$. Nadal (2000b: 39) plantea que el hecho de que la disminución del precio real de producción del maíz no se haya reflejado en el precio de la tortilla se explica porque existe un mercado oligopólico en el insumo prin- 
Gráfica 7. Incremento porcentual en el precio al consumidor y productor. Principales alimentos (1995-2005)

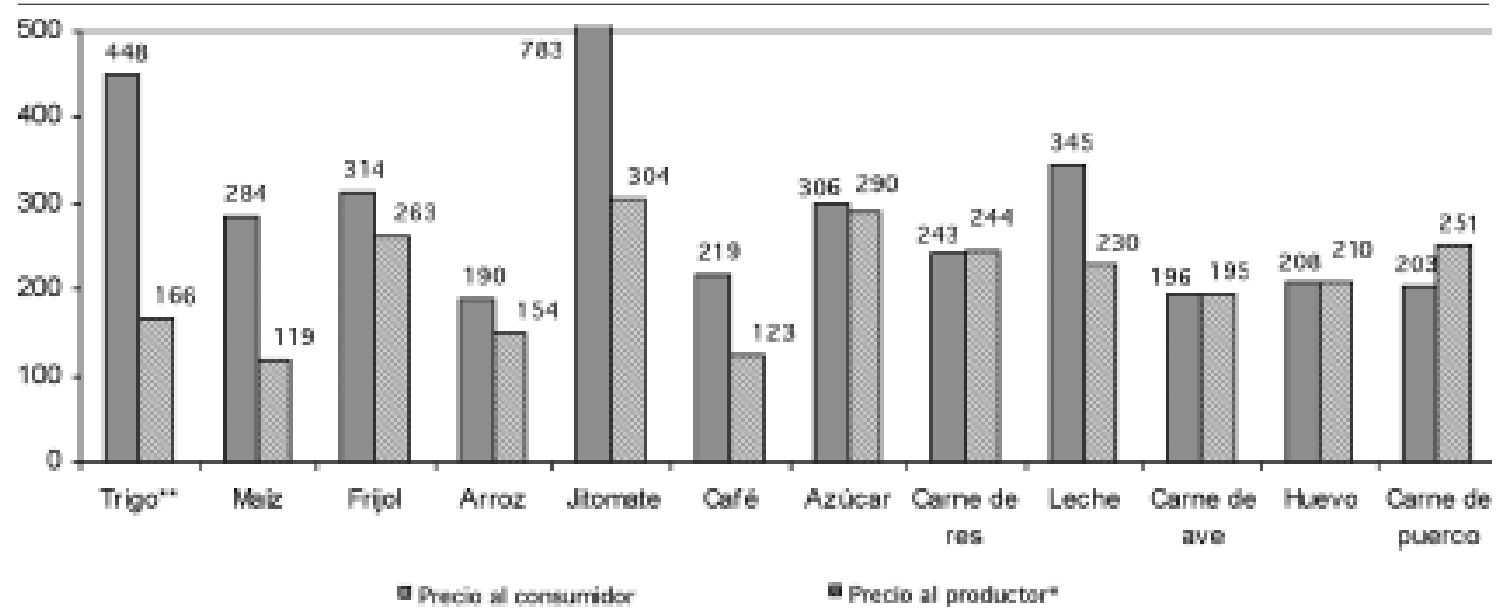

* Precios en la finca o granja.

** El precio al consumidor corresponde a harina de trigo

FUENTE: Elaborado con base en: OECD, PSE-CSE Database 2006 (para precios al productor); Banco de México, INPC (para precios al consumidor).

cipal de este producto, ya que cuatro firmas nacionales controlan el total del mercado de harina de maíz y de ellas, una sola, Maseca, acapara $71 \%$ del mercado (SIAP, 2007: 57-58).

Los precios de consumo de los otros alimentos básicos han tenido un comportamiento similar al del maíz: el chile, sólo entre diciembre de 1994 y abril de 2007, se ha encarecido en $1418 \%$ en promedio (recuérdese que hay muchas variedades de chile), en tanto que la leche, los productos hortofrutícolas y el frijol lo han hecho en 415 , 428 y $370 \%$ respectivamente (gráfica 6, p. 67).

La situación anterior se agrava al comparar los incrementos aludidos con lo sucedido a los salarios. En el caso del salario mínimo general, el aumento entre diciembre de 1993 y abril de 2007 fue de sólo 274\%, es decir, menos que el costo de la vida, por lo que el salario mínimo real ha decrecido en $21 \%$ en ese periodo. Por su parte, el salario promedio manufacturero, aunque se ha incrementado $6 \%$ en términos reales, dicho aumento no es suficiente para compensar los incrementos en los precios de los alimentos básicos. Por lo tanto, la apertura comercial, lejos de abaratar el costo de la vida para las familias más necesitadas, lo ha incrementado, lo cual hace inseguro el acceso a los alimentos y más vulnerable la situación de la población trabajadora.

Ahora bien, si el precio de los alimentos ha crecido más que la inflación, pudiera pensarse que los agricultores son los beneficiados. Sin embargo, la situación es muy diferente, pues entre 1995 y 2005, de los doce productos contemplados en la gráfica 7 , en nueve de ellos el precio al consumidor aumentó más que el que recibió el productor, siendo los casos más extremos los del jitomate, el trigo, el maíz, la leche y el café. En cambio, en ninguno de estos productos el incremento en el precio al productor fue superior a la inflación (que en ese periodo fue de $327 \%$ ).

\section{Condiciones de inseguridad en el acceso al empleo}

El empleo en el campo ha venido descendiendo de manera constante en los últimos años como resultado del desplazamiento de la población económicamente activa (PEA) del sector primario a los sectores secundario y terciario, pero también por la drástica pérdida de empleo en el agro que supera con mucho lo sucedido en el resto de 
Cuadro 3. Empleo generado en el sector agropecuario

\begin{tabular}{lccccc}
\hline Periodo & $\begin{array}{c}\text { Crecimiento de } \\
\text { la PEA rural }\end{array}$ & $\begin{array}{c}\text { Empleo rural } \\
\text { generado en } \\
\text { industria } y \text { servicios }\end{array}$ & $\begin{array}{c}\text { Empleo generado } \\
\text { en el agro }\end{array}$ & $\begin{array}{c}\text { Déficit de empleo } \\
\text { rural }\end{array}$ & $\begin{array}{c}\text { Déficit de empleo } \\
\text { en el agro }\end{array}$ \\
\hline $2000-2006^{* *}$ & -423733 & 546600 & -1063083 & 92750 & 639350 \\
\hline
\end{tabular}

* Calculado con base en la población ocupada.

** Del segundo trimestre de 2000 al segundo trimestre de 2006

FUENTE: Elaborado con base en Fox, 2006: 226, 236.

Cuadro 4. Crecimiento de la población inmigrante de México en Estados Unidos y de la población de México

\begin{tabular}{l|c|c|c|c}
\hline Año & $\begin{array}{c}\text { Población mexicana } \\
\text { en Estados Unidos }\end{array}$ & Periodo & $\begin{array}{c}\text { Tasa de crecimiento anual } \\
\text { promedio de inmigrantes } \\
\text { mexicanos en Estados Unidos }\end{array}$ & $\begin{array}{c}\text { Tasa de crecimiento anual } \\
\text { promedio de la población } \\
\text { en MéxicoV }\end{array}$ \\
\hline $1960^{\mathrm{I}}$ & 575902 & $1960-1970$ & $2.8 \%$ & 3.14 \\
\hline $1970^{\mathrm{II}}$ & 759711 & $1970-1980$ & $11.2 \%$ & 2.89 \\
\hline 1980 & 2199221 & $1980-1990$ & $6.7 \%$ & 2.08 \\
\hline 1990 & 4199221 & $1990-2002$ & $7.4 \%$ & $1.80^{\mathrm{VI}}$ \\
\hline $2002^{\mathrm{III}}$ & 9900414 & $2002-2004$ & $3.7 \%$ & $1.00^{\mathrm{VII}}$ \\
\hline $2004^{\mathrm{IV}}$ & 10638000 & & & \\
\hline
\end{tabular}

I Pellegrino (2003).

II 1970-1990: CELADE (2000).

III U.S. Census Bureau (2002), Current Population Survey, March Supplement.

IV U.S. Census Bureau (2004), Current Population Survey. Annual Social and Economic Supplement. Ethnicity and Ancestry Statistics Branch. Population Division.

V INEGI, Censos de población de México, 1960, 1970, 1980, 1990, 2000 y Conteo de población, 2005.

VI Corresponde al periodo 1990-2000.

VII Corresponde al periodo 2000-2005

la economía. Mientras que la población ocupada en toda la economía de México creció entre 1998 y el primer trimestre de 2007 en $9.68 \%$, en el sector agropecuario disminuyó en $23.97 \%$ al pasar de 7.5 millones de personas a sólo 5.7 millones ${ }^{22}$. De igual manera, mientras que el número de trabajadores registrados ante el Instituto Mexicano del Seguro Social (IMSS) creció 41.02\% entre 1998 y 2007 (hasta abril), los asegurados en el campo disminuyeron $27.83 \%$ y, lo que es más grave, la mayor pérdida se dio en el caso de los trabajadores permanentes, cuya cifra bajó $29.09 \%{ }^{23}$. Esto implica que no sólo hay pérdida de oportunidades de trabajo en el campo, sino

22 Secretaría del Trabajo y Previsión Social (STyPS), Encuesta Nacional de Empleo (de 1998 a 2007).

23 INEGI, Banco de Información Económica, op. cit. que el poco empleo que se está generando es de trabajadores eventuales, que como tales tienen una escasa seguridad laboral, además de que generalmente son empleos de más baja calidad que los permanentes y, por lo mismo, reciben salarios inferiores.

Las condiciones de inseguridad creciente para la población agropecuaria trabajadora se pueden apreciar con mayor realismo al cotejar el crecimiento de la PEA y el comportamiento del empleo. En lo que va de este siglo hasta el segundo trimestre de 2006, se perdieron 1.06 millones de puestos de trabajo en la agricultura, cuando la PEA rural disminuyó en 423733 personas. Es decir, a pesar de que la población en edad de trabajar en el campo disminuyó por efecto de la migración a zonas urbanas y, sobre todo, a Estados Unidos, hay un déficit laboral en la agricultura que asciende a 639350 puestos de 


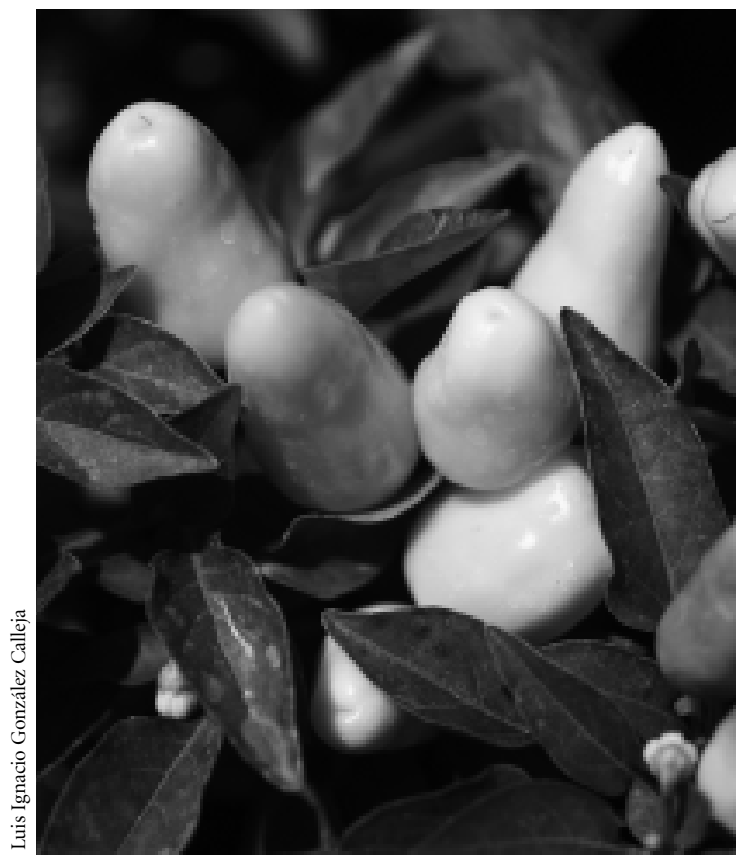

Una de tantas variedades de chile.

trabajo, mismo que tendría grandes repercusiones económicas y sociales en las zonas rurales del país de no ser porque otros sectores de la economía rural (industria y servicios) crearon 546600 empleos (cuadro 3, p. 69).

Por eso Gómez Cruz y Schwentesius (2003: 54) destacan el hecho de que en el periodo de vigencia del TLCAN hasta 2002, casi 600 mil productores de granos básicos, $40 \%$ de los porcicultores y $24 \%$ de los productores de papa ya habían abandonado su actividad; igualmente, un cálculo elaborado a partir de los datos propuestos por Nadal (2000a: 4) nos permite suponer que alrededor de 270 mil productores de maíz han desaparecido en los últimos doce años (véase nota 16, p. 61), y aunque algunos se ubicaron en otras actividades productivas del agro (como los que cambiaron de estos cultivos a las frutas y hortalizas) o del sector industrial y de servicios, la mayoría quedaron desempleados, tuvieron que emigrar o se incorporaron al sector informal.

Con ello el discurso gubernamental en pro de la apertura comercial, que planteó que las pequeñas unidades de producción serían sustituidas por agroempresas grandes y competitivas y que éstas, junto con las empresas industriales y de servicios, darían empleo a campesinos y pequeños productores desempleados, ha sido completamente rebasado por la realidad. Hoy los trabajadores mexicanos, y en particular los del campo, son más vulnerables que antes, con cada vez menos oportunidades de empleo tanto por el elevado crecimiento de la PEA en el país (debido a que en las décadas de 1970 y 1980 la tasa de natalidad fue muy alta) como por la poca capacidad de la economía para generar mayores fuentes de trabajo y por los efectos negativos que en ella ha generado la apertura comercial.

Frente a la vulnerabilidad que enfrentan la población rural y los trabajadores del campo, una alternativa recurrente ha sido la migración, principalmente hacia Estados Unidos. El cuadro 4 (p. 69) muestra cómo la tasa de crecimiento de los inmigrantes mexicanos a ese país se ha incrementado ostensiblemente en las últimas cuatro décadas, con valores que claramente superan el crecimiento de la población. En 2004 eran casi 11 millones los inmigrantes mexicanos en Estados Unidos, de los cuales se calcula que $90 \%$ son de origen campesino (Ramírez, 2003).

Para la economía de México, y en particular de muchas de las localidades rurales del país, la migración se ha vuelto un factor cada vez más importante de sobrevivencia gracias a las remesas que se reciben. En 2006 éstas sumaron 23054 millones de dólares (mdd), y desde 2005 se han convertido en la segunda fuente de divisas para el país ${ }^{24}$. Además, esta situación tiende a intensificarse toda vez que la tasa anual de crecimiento de las remesas entre 1994 y 2005 fue de 18.2\%, muy superior a la de los ingresos por petróleo $(14.6 \%)$, turismo $(7.5 \%)$ o inversión extranjera directa (6.5\%).

Aun así, la migración a Estados Unidos no es ni debe ser una solución al problema económico de la población mexicana. A pesar de que es una muy importante válvula de escape, significa una pérdida de capital humano para México. Aunque las remesas alivian la situación de las familias de los migrantes, no deja de ser una situación de

\footnotetext{
${ }^{24}$ Banco de México, balanza de pagos, Estadísticas, op. cit.
} 
vulnerabilidad para los mismos porque dependen del trabajo ilegal en otro país (en 2004, 81\% de los migrantes mexicanos en Estados Unidos todavía no tenían la ciudadanía de aquel país ${ }^{25}$ ) y porque no tienen ninguna seguridad en el empleo, pues buena parte de los trabajos son eventuales y no cuentan con los sistemas de seguridad social que sí disfrutan los trabajadores legalmente instalados en Estados Unidos. Además, este fenómeno sólo demuestra el fracaso del "desarrollo" socioeconómico mexicano, el cual ha acentuado la desigualdad económica.

\section{Condiciones de la alimentación de la población en México}

Los valores nutricionales de la alimentación de los mexicanos han crecido a tasas muy bajas en los últimos años. Entre 1969 y 1981 México tenía un mayor crecimiento en el consumo diario per cápita de proteínas y calorías que los promedios de América Latina y los países en desarrollo. Sin embargo, en el periodo de la crisis, entre 1982 y 1992, el país tuvo retrocesos y aunque en el periodo de vigencia del TLCAN hasta 2004 ha vuelto a crecer el consumo per cápita, sus tasas de crecimiento son inferiores a las de América Latina y el promedio de los países en desarrollo (gráfica 8, p. 72).

Esto denota que la política económica tampoco ha influido de manera determinante en una mejora en la alimentación de los mexicanos pues, si así fuera, por lo menos el crecimiento de los últimos años debería ser superior al de Latinoamérica.

\section{Condiciones de pobreza de la población en México}

El Banco Mundial define como pobres a aquellas personas cuyos ingresos se ubican por debajo de los niveles juzgados como necesarios para sostener un nivel de vida digno $^{26}$. En cuanto a la pobreza extrema, ésta significa es-

25 U. S. Bureau, 2004, op. cit.

26 Para identificar a quienes están por debajo de ese nivel, se utilizan tres tar por debajo de la línea de ingresos para una alimentación básica, que en el caso de México implica tener un ingreso inferior a dos dólares diarios.

En el año 2004 los pobres representaron $47 \%$ de la población total del país, de los cuales $17.3 \%$ se ubicaba en pobreza extrema. Si se comparan los datos anteriores con los de 1992 (un poco antes de que entrara en vigor el TLCAN), podemos observar que efectivamente la pobreza ha disminuido, pues en aquel año era de 52.6\% (cuadro 5, p. 73). De acuerdo con el cuadro 5, la mayor disminución de la pobreza se da a partir de 2002, pero en ese año hubo un cambio en la metodología de la Encuesta Nacional de Ingresos y Gastos de los Hogares (ENIGH) respecto del año 2000, lo que, de acuerdo con algunos investigadores como Fernando Cortés (2005), cuestiona la

líneas. De acuerdo con la Secretaría de Desarrollo Social (Sedesol) (mencionadas por el Banco Mundial, 2004: 8-9), éstas se definen de la siguiente forma: "La primera es la línea de pobreza basada en la alimentación, que es un estimado del ingreso requerido para comprar una canasta de alimentos para satisfacer un mínimo de requerimientos nutricionales. La Canasta Básica de Alimentos (CBA) fue definida y calculada por el Instituto Nacional de Estadística, Geografía e Informática (INEGI) en colaboración con la Comisión Económica para América Latina y el Caribe (CEPAL). Esta canasta se calcula por separado para las áreas rurales y urbanas, y se basa en los patrones de gasto en alimentos de los hogares que apenas satisfacen los requerimientos mínimos de alimentos nutritivos, suponiendo que todo el gasto fuera en comida. Esto se calcula para las áreas urbanas y rurales. Luego, la línea de pobreza en alimentos se deflacta utilizando índices de precios al consumidor por alimentos específicos que elabora el Banco de México. Para calcular la segunda línea de pobreza, los gastos y las proporciones de alimento se clasifican por gastos totales per cápita con base en la Encuesta Nacional de Ingresos y Gastos de los Hogares (ENIGH). Al intersectarse la línea de pobreza estimada uno con la línea de gasto en alimentos y tomar un rango de unos cinco puntos porcentuales a cada lado de esta intersección, se utiliza el componente promedio no destinado a alimentos para determinar la línea de pobreza dos. Luego la Sedesol introdujo una tercera línea intermedia, con el fin de observar algo por encima de la línea basada en los alimentos". El cuadro siguiente presenta las líneas de pobreza oficiales, como las utiliza Sedesol:

Líneas de pobreza oficiales en pesos correspondientes al mes de agosto del año de estudio

\begin{tabular}{lccrrc}
\hline & Zona & 1992 & 2000 & 2002 & 2004 \\
\hline Alimentaria & Urbana & 168.0 & 626.0 & 672.3 & 739.6 \\
\hline De capacidades & Rural & 124.7 & 462.9 & 494.8 & 548.2 \\
\hline & Rural & 140.5 & 548.4 & 587.3 & ND \\
\hline De patrimonio & Urbana & 333.1 & 1255.3 & 1367.4 & ND \\
\hline & Rural & 218.8 & 842.6 & 946.5 & ND \\
\hline
\end{tabular}


Gráfica 8. Crecimiento promedio anual en el consumo per cápita de calorías y proteínas

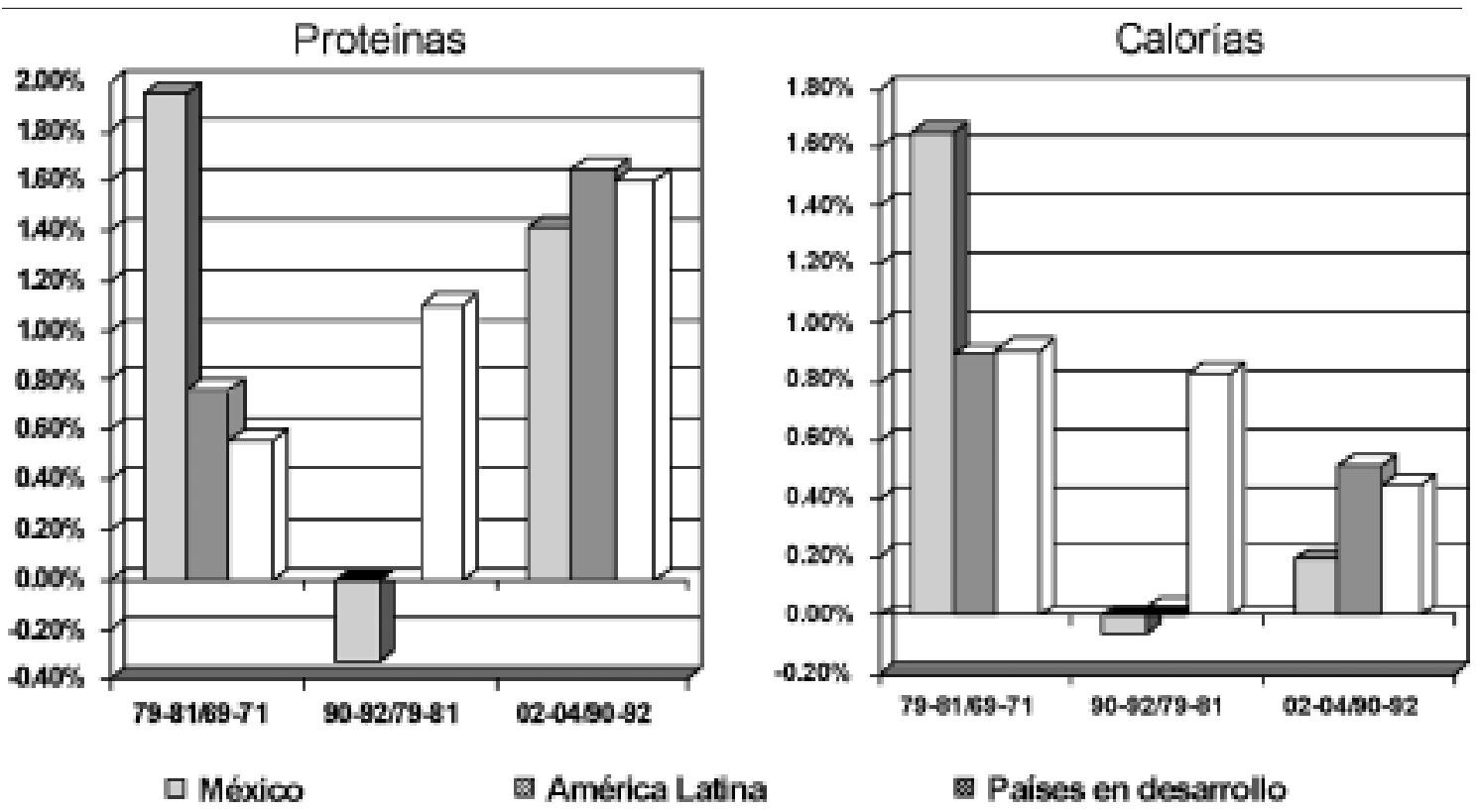

FUENTE: Elaborado con base en datos de la FAO, Statics Division, Food Consumption Nutrients.

comparación de los datos 27 . Pero aún si así fuera, lo que habría que preguntarse es si a más de veinte años de una apertura económica y comercial que prometía mejorar las condiciones de vida del mexicano, se puede considerar exitoso el hecho de que todavía prácticamente la mitad de la población mexicana siga siendo pobre.

La disminución más importante se da en el caso de la pobreza extrema, que pasó de 22.5 a $17.3 \%$ de la población nacional. Muchos mexicanos dejaron de ser pobres extremos pero siguen siendo pobres, pues la pobreza moderada sólo disminuyó de 30.1 a 29.7\%.

\footnotetext{
${ }^{27}$ Este autor argumenta que el crecimiento de los ingresos en 2002 "se debió a factores tales como la separación de conceptos que antes se captaban en grupo, el desdoblamiento de una misma pregunta y preguntas nuevas que captaron ingresos que no estaban incluidos en el cuestionario de la ENIGH 2000". En todo caso, de acuerdo con este autor, "sólo la pobreza de capacidades al nivel nacional y urbano, así como la alimentaria nacional y rural tuvieron una caída que debiera ser explicada por factores más allá del azar. [Por el contrario], la disminución en todas las demás no supera las fluctuaciones de muestreo por lo que la baja en la incidencia de la pobreza se podría explicar por el azar" (Cortés, 2005: 31).
}

Aunque la pobreza se presenta tanto en áreas urbanas como rurales, resulta evidente que es más severa en las últimas, pues mientras $11 \%$ de la población urbana se sitúa por debajo de la línea de pobreza alimentaria, $27.6 \%$ de la población rural se encuentra en esa condición (aunque en el año 2000 era de 42.4\%). Además, casi seis de cada diez habitantes en los territorios rurales son pobres.

Todo lo anterior nos lleva a señalar que los cambios en la política económica de México desde finales de la década de 1980, cuando se liberalizó la economía, tampoco han remediado el grave problema de pobreza que se vive en México e, incluso, lo han agravado entre los habitantes que se dedican a la producción agropecuaria. En las zonas rurales, siete de cada diez mexicanos que vivían en pobreza extrema en 2002, y en las zonas urbanas casi cinco de cada diez, se dedicaban a la agricultura y a la ganadería (cuadro 5, p. 73).

Además, los trabajadores que han resultado más perjudicados por la aplicación de las políticas de apertura y 
Cuadro 5. Evolución de la pobreza en México (porcentaje de personas pobres)

\begin{tabular}{|c|c|c|c|c|}
\hline & \multicolumn{4}{|c|}{ Año } \\
\hline & 1992 & 2000 & 2002 & 2004 \\
\hline Pobreza extrema (alimentaria) (A) & 22.5 & 24.2 & 20.3 & 17.3 \\
\hline Urbano & 13.5 & 12.6 & 11.4 & 11.0 \\
\hline Rural & 35.6 & 42.4 & 34.8 & 27.6 \\
\hline Rural y se dedican a agricultura* & 69.1 & ND & 71.7 & ND \\
\hline Jornaleros agrícolas ${ }^{\star *}$ & 22.7 & ND & 24.3 & ND \\
\hline Pobreza moderada (B) & 30.1 & 29.5 & 30.3 & 29.7 \\
\hline Urbano & 30.5 & 31.2 & 30.1 & 30.0 \\
\hline Rural & 29.4 & 26.9 & 30.6 & 29.3 \\
\hline Rural y se dedican a agricultura* & 52.5 & ND & 47.2 & ND \\
\hline Jornaleros agrícolas ${ }^{* *}$ & 8.5 & ND & 9.3 & ND \\
\hline Pobreza total (de patrimonio) $(\mathrm{A}+\mathrm{B})$ & 52.6 & 53.7 & 50.6 & 47.0 \\
\hline Urbano & 44.0 & 43.8 & 41.5 & 41.0 \\
\hline Rural & 65.0 & 69.3 & 65.4 & 56.9 \\
\hline
\end{tabular}

* Se refiere a la proporción de quienes se dedican a la agricultura respecto al total de sectores de actividad productiva.

** Se refiere a la proporción de jornaleros agrícolas dentro del total de tipo de empleos existentes.

$\mathrm{ND}=$ No disponible.

FUENTE: Fox (2006: 91). La fuente para los perfiles señalados en las notas ${ }^{\star} y^{\star \star}$ es Banco Mundial (2004).

desregulación económica son precisamente los del campo. De acuerdo con el perfil de empleo, los jornaleros agrícolas aumentaron su participación en la pobreza extrema entre 1992 y 2002 de 22.7 a $24.3 \%$ y de 8.5 a $9.3 \%$ en pobreza moderada ${ }^{28}$. Esto echa abajo el argumento que señalaba que con la creación de grandes empresas agroalimentarias en el campo, al aumentar la productividad y la competitividad, los ingresos de los trabajadores se incrementarían (aun cuando, según el Banco Mundial [2004: xx], entre 2000 y 2002 los salarios rurales no calificados sí lo hicieron en 20\%).

Finalmente, cabe señalar que los cambios en los niveles de pobreza dependen de la combinación de dos fac-

${ }^{28}$ El otro grupo de trabajadores que también aumentó su participación en la pobreza son los autoempleados, es decir, aquellos que en general han sido desplazados del mercado laboral por la incapacidad de la economía para generar empleos. tores: por un lado, los cambios en los ingresos reales de la población; por otro, los niveles de desigualdad en la distribución del ingreso. Respecto a los cambios en los ingresos, ya vimos que en México el crecimiento del salario mínimo ha sido negativo en términos reales en los últimos años, en tanto que el aumento en el precio de la canasta básica y de una gran mayoría de alimentos ha sido muy superior a la inflación.

En cuanto a la distribución del ingreso, medida por el coeficiente de Gini, la desigualdad en México es bastante alta, pues de acuerdo con el Banco Mundial (2004: xxiv), alcanza valores que fluctúan entre 0.50 y 0.55 en el periodo de 1992 a $2002^{29}$. Esto de nuevo hace más preocupan-

\footnotetext{
${ }^{29}$ El coeficiente de Gini fluctúa entre 0 y 1 , en el que 0 es la situación en que todos los individuos o familias de una comunidad tienen el mismo ingreso. Por su parte, un valor de 1 significaría que los ingresos se concentran en unos pocos hogares o individuos. En términos prác-
} 


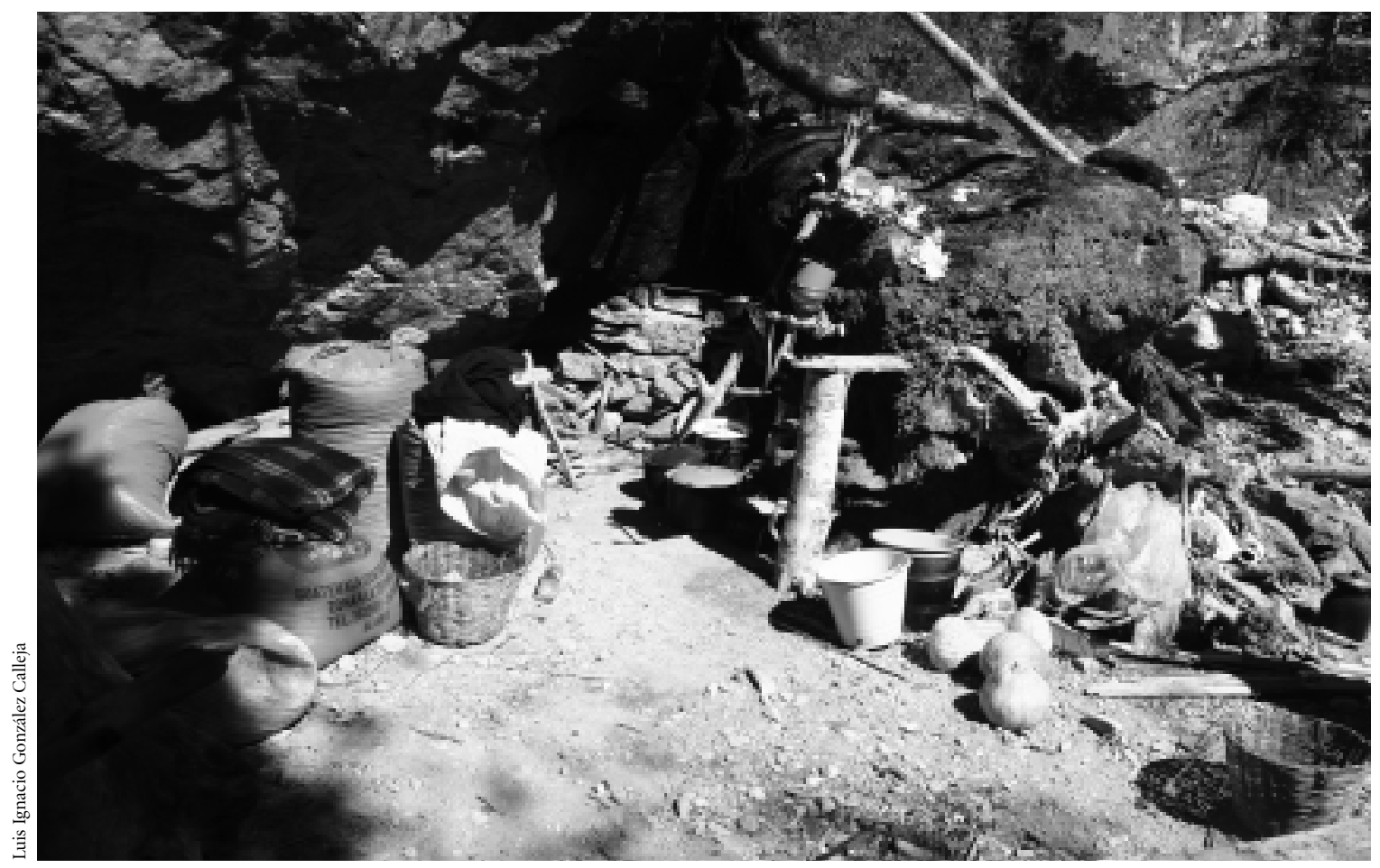

Pobreza extrema.

te lo sucedido en las zonas rurales del país, pues mientras que la desigualdad en el ingreso se ha venido reduciendo en las áreas urbanas (de 0.49 a 0.46 entre 1992 y 2002), en las rurales ha sucedido exactamente lo contrario, sobre todo a partir de la recuperación de la economía en 1996, pues en 1994 el valor era de 0.44 y en 2000 llegó hasta 0.53 (en 2002 bajó a 0.49).

\section{CONCLUSIONES}

La ideología neoliberal que guía la política agroalimentaria en México ha centrado su atención en indicadores principalmente macroeconómicos y en el incremento de

ticos, valores de hasta 0.30 señalan que hay una distribución del ingreso más o menos equitativa, mientras que hay desigualdad cuando el coeficiente de Gini se encuentra en el intervalo de 0.40 a 0.60 . Más de 0.60 refleja una distribución gravemente inequitativa. la productividad y la competitividad de las actividades primarias, sin deparar en la especificidad e importancia que tienen frente a otros sectores de la economía; además, no ha dado importancia al contexto histórico y sociocultural de los productores nacionales y a su posición desigual frente a los productores de otras naciones, con quienes han tenido que competir de manera desventajosa. Finalmente, no ha concedido prioridad al desequilibrio y a la degradación ambiental que se presentan con las iniciativas tomadas. Esta política reduccionista y simplificadora, aplicada de manera autoritaria por el Estado mexicano, ha conducido al país a una mayor vulnerabilidad alimentaria y ha acentuado las desigualdades entre el campo y la ciudad y entre los diferentes sectores socioeconómicos.

En el estudio de este proceso consideramos, en primer lugar, la vulnerabilidad agroeconómica que nos muestra una sociedad nacional más vulnerable debido a una disminución en la tasa de crecimiento promedio de la producción de alimentos básicos (cereales, leguminosas, 
carnes, leche y oleaginosas) y en su distribución por habitante; y también, una balanza comercial agrícola crecientemente deficitaria. La productividad que observamos en algunos cultivos, particularmente en el maíz, se mantiene por debajo del incremento en la productividad que lograron sus principales socios comerciales. Con ellos, los productores nacionales han tenido que competir en condiciones desiguales, debido a los subsidios que ofrecen sus gobiernos y a la falta de protección comercial por parte del gobierno de México, que ha renunciado a aplicar aranceles y salvaguardas para proteger a los productores nacionales. La situación más crítica está por venir en 2008, cuando se termina el plazo de protección para la producción nacional de maíz y de frijol y el mercado nacional se abre a las importaciones de Estados Unidos.

El objetivo de dinamizar la economía a partir de un incremento en la productividad y la competitividad se alcanzó en un cierto grupo de productos, como las frutas y las hortalizas. Éstos tuvieron una importancia creciente en el valor de la producción nacional y en las exportaciones agropecuarias. El desarrollo de estos cultivos, sin embargo, cada vez más se concentra en un número reducido de regiones y de empresas. Las más dinámicas de estas últimas se han asociado al capital extranjero o están supeditadas a él para su financiamiento y para la comercialización de sus productos en el extranjero.

Hoy en día, México depende cada vez más del mercado mundial para atender su demanda creciente de alimentos y responder a las situaciones de emergencia que se presentan con las sequías y los desastres naturales. Esta dependencia compromete recursos económicos que podrían utilizarse para dinamizar la economía y atender la demanda creciente de empleo; además, vuelve más vulnerable a la sociedad nacional en la medida en que para satisfacer su demanda creciente de alimentos, cada vez depende más de las variaciones de precio de los alimentos en el mercado internacional y de la política económica y de seguridad nacional de los países exportadores. La mayor parte de las importaciones de alimentos de México y casi la totalidad de sus exportaciones agropecuarias se concentran en Estados Unidos, país con una agresiva política nacionalista a escala global y con una trayectoria en el manejo político de sus exportaciones de alimentos. Con ello, el gobierno mexicano ha perdido autonomía en el manejo de su política agroalimentaria.

En segundo lugar, consideramos la vulnerabilidad ambiental, que se manifiesta en la falta de una política clara orientada a preservar y desarrollar la biodiversidad y la riqueza fitogenética de México. Esta situación ha estado relacionada con la disminución de las oportunidades de vida de los pequeños productores campesinos, quienes durante siglos han desarrollado diversidad de razas y variedades de los cultivos básicos, particularmente en el caso del maíz. Estos productores, ante la imposibilidad de competir con los productos importados, han tenido que recurrir a terrenos marginales y desforestar bosques y selva para autoabastecerse de los alimentos básicos que necesitan. Además, han tenido que migrar interna e internacionalmente para poder sobrevivir y abandonar la agricultura. A causa de esta situación, disminuye la posibilidad de mantener las razas tradicionales de los cultivos y las variedades silvestres en los lugares de donde son originarios. A lo anterior se suman los programas gubernamentales para difundir el uso de semillas híbridas entre los campesinos y, sobre todo, la entrada sin control de semillas transgénicas de maíz, lo que pone en riesgo el patrimonio biogenético de esta planta, que es el cultivo que más se produce en México y en el mundo.

Por otra parte, el desarrollo intensivo de monocultivos comerciales para el mercado de exportación ha implicado la degradación y contaminación de los ecosistemas en las áreas donde se producen. Esta situación no ha recibido atención por parte de las autoridades.

En tercer lugar consideramos la vulnerabilidad social y advertimos que la política económica y agropecuaria ha agudizado la vulnerabilidad de los sectores con menos ingresos, particularmente en las áreas rurales. Para ellos los alimentos son más costosos mientras que los salarios son menos suficientes debido a la creciente pérdida de su valor real, además de que se ha incrementado el desempleo, particularmente en las áreas rurales. Esta situación explica en buena medida el hecho de que ha habido un deterioro en los valores nutricionales de la población desde 1982 a 2003, el cual se advierte en el retroceso del consumo per cápita de proteínas y calorías en la población mexicana. 
Bajo estas circunstancias, los niveles de pobreza han crecido; no obstante, se observa una mejoría en los índices de pobreza extrema. Las remesas de los migrantes de México hoy día constituyen una entrada neta de divisas mayor que la inversión económica directa o el turismo, y son la fuente de subsistencia para las familias de los migrantes en las áreas de agricultura de subsistencia. Los migrantes mexicanos en Estados Unidos - la mayoría de ellos ilegales- padecen restricciones para ejercer sus derechos laborales y humanos y, al igual que los más pobres de México, enfrenten una situación vulnerable en su trabajo y en su ingreso.

\section{Bibliografía}

Agustín, J., G. Arteaga, M. Blancarte, H. Calderón, V. López, D. Rivera, S. Rivera, J. Romero y C. Santos, 1994, La producción agropecuaria de la región valle del Tepalcatepec, Michoacán, Universidad Autónoma de Chapingo, Texcoco, Estado de México.

Álvarez-Buya, E., 2004, "Aspectos ecológicos, biológicos y de agrobiodiversidad de los impactos del maíz transgénico", en J. Muñoz (coord.), Alimentos transgénicos. Ciencia, ambiente y mercado: Un debate abierto, Universidad Nacional Autónoma de México, Siglo XXI, México, pp. 181-218.

Altieri, M., 1990, "Agroecology and Rural Development in Latin America", en M. Altieri y S. Hecht (eds.), Agroecology and Small Farm Development, CRC Press, Estados Unidos, pp. 113-118.

Banco Mundial, 2004, La pobreza en México: una evaluación de las condiciones, las tendencias y la estrategia del gobierno, Banco Internacional de Reconstrucción y Fomento, Banco Mundial, Washington.

Barry, M., 2000, "Effect of the U.S. Embargo and Economic Decline on Health in Cuba", Annals of Internal Medicine, vol. 132, núm. 2, pp. 151-154.

Beck, U., 1997, Risk Society. Towards a New Modernity, Sage, Londres.

Berthaud, J. y P. Gepts, 2004, "Evaluación de los efectos en la diversidad genética", en Comisión de Cooperación Ambiental, Informe del Artículo 13 del ACAAN. Maíz y biodiversidad: efectos del maíz transgénico en México, cap. 3.

Blaikie, P., T. Cannon, I. Davis y B. Wisner, 1996, Vulnerabilidad. El entorno social, politico y económico de los desastres, Red de Estudios Sociales en Prevención, Colombia.

Brathwaite, Ch., 2004, "Retos científicos y políticos para la toma de decisiones sobre cambio climático y seguridad alimentaria", discurso pronunciado en el Foro Científico Político "Cambio ambiental global, globalización y sistemas alimentarios", IICA, 5 de noviembre.

Braun, J. Von et al., 1992, Improving Food Security of the Poor: Concept, Policy and Programs, IFPRI, Washington.

Bustamante, T., 1996, Las transformaciones de la agricultura o las paradojas del desarrollo regional: el caso de los valles de Tierra Caliente, Guerrero, Juan Pablos, México.

Calva, J. L., 1993, La disputa por la tierra, Fontamara, México. __ 1994, "La reforma neoliberal del régimen agrario mexicano. Implicaciones en el largo plazo", en E. Ochoa y D. Loret (eds.), Estado y agricultura en México. Antecedentes e implicaciones de las reformas salinistas. Universidad Metropolitana, México, pp. 140-166.

CELADE (Centro Latinoamericano de Demografía), 2000, Boletín Demográfico, núm. 65, enero.

Chapela, I., 2005, "Ley de 'colonización genética", Noticias, 9 de febrero, Oaxaca, $(<\mathrm{http}: / /$ www.noticias-oax.com. $\mathrm{mx} /$ articulos.php?id_sec=5\&id_art=27363\&id_ejemplar $=668>$ ).

Conde, C., R. Ferrer, C. Gay y R. Araujo (2004), "Impactos del cambio climático en la agricultura en México", en J. Martínez y A. Fernández (comps.), Cambio climático. Una visión desde México, Instituto Nacional de Ecología, México, pp. 227-238.

Cook, R. y R. Amon, 1989, "Competition in the Fresh Vegetable Industry", en Competitiveness at Home and Abroad, reporte de 1986-1987 del Study Group on Marketing California Specialty Crops: World Competition and Constraints, Universidad de California, Agricultural Issues Center.

Cortés, F., 2005, ¿Disminuyó la pobreza? México 2000-2002, Secretaría de Desarrollo Social, México (Serie Documentos de Investigación, núm. 21).

FAO, 1975, Report of the World Food Conference, Roma, 5-16 de noviembre de 1974, ONU, Nueva York.

—_, 1983, World Food Security: A Reappraisal of the Concepts and Approaches. Director General's Report, FAO, Roma.

__ 1993, "Safeguarding the Diversity of Plant Genetic Resources", en World Agriculture 1993, FAO, Roma.

— 1996, Synthesis of the Technical Background Documents, Cumbre Mundial de la Alimentación en Roma, 13-17 de noviembre, FAO, Roma.

Fischer, G., M. Shah y H. Van Velthuizen, 2002, Climate Change and Agricultural Vulnerability, International Institute for Applied Systems Analysis, ONU.

Fox, V., 2006, Sexto informe de gobierno, Presidencia de la República, México.

Freese, W y D. Schubert, 2004, "Safety Testing and Regulation of Genetically Engineered Foods", Biotechnology \& Genetic Engineering Reviews, vol. 21, pp. 299-324. 
García, V., 2005. "El riesgo como construcción social y la construcción social de riesgos”, Desacatos, núm. 19, pp. 11-24.

Garrido, C. y C. Leriche, 1998, "Grandes grupos empresariales privados nacionales, crisis bancarias y Fobaproa”, El Cotidiano. Revista de la Realidad Mexicana Actual, año 15, noviembre-diciembre, Universidad Autónoma Metropolitana, pp. 16-26.

Gay, C., s. f., Cambio climático en México, Centro de Ciencias de la Atmósfera, México.

Girón, A., 1994, "La banca comercial de México frente al TLC", Comercio Exterior, vol. 44, núm. 12, pp. 1068-1074.

Gómez Cruz, M.y R. Schwentesius, 2003, "Impacto del TLCAN en el sector agroalimentario mexicano: evaluación a diez años", en S. Anderson, A. Arroyo, J. Dillon, J. Foster, M. Gómez Cruz, K. Hansen-Kuhn, D. Ranney, R. Schwentesius, Lecciones del TLCAN: el alto costo del "libre" comercio, Alianza Social Continental, Red Mexicana de Acción Frente al Libre Comercio, México, pp. 44-60.

González, H., 1994, El empresario agrícola en el jugoso negocio de las frutas y hortalizas en México, Universidad de Wageningen, Holanda.

_ 1998 , "Las asociaciones locales de productores frente al centralismo y a la discontinuidad de la política agrícola del Estado mexicano", Estudios Sociológicos, vol. XVI, núm. 48, pp. 689-710.

_ 2004 , "La sustentabilidad y las cadenas globales de mercancías: la agricultura de exportación en México", en M. del Valle (ed.), El desarrollo agrícola y rural del tercer mundo en el contexto de la mundialización, Universidad Nacional Autónoma de México, Plaza y Valdés, México, pp. 227-260.

González, M., 2006, “Introducción”, en M. González (ed.), Procesos domésticos y vulnerabilidad, Centro de Investigaciones y Estudios Superiores en Antropología Social, México, pp. 11-44.

Goodman, D. y M. Redclift, 1991, Refashioning Nature. Food, Ecology and Culture, Routledge, Londres y Nueva York.

Goodman, M. y L. García Barrios, 2004, "Evaluación de los efectos biológicos en la agricultura”, en Comisión de Cooperación Ambiental, Informe del Artículo $13 \mathrm{del}$ ACAAN. Maíz y biodiversidad: efectos del maíz transgénico en México, cap. 5.

Granovetter, 1985 "Economic Action and Social Structure: the Problem of Embeddedness", American Journal of Sociology, vol. 9, núm. 3, pp. 481-491.

Granovetter, 1992 "Economic Institutions as Social Constructions: A Framework for Analysis", Acta Sociológica, vol. 35, núm. 1, pp. 3-11.

Greenpeace México, 2007, "Más del 90\% del arroz importado está contaminado", nota aparecida el 30 de marzo, en $<$ http://www.greenpeace.org/mexico/news/mas-del90-del-arroz-importad>, consultado el 25 de abril de 2007.

Henriques, G. y R. Patel, 2004, "NAFTA, Corn, and Mexico's Agricultural Trade Liberalization", Americas Program, 13 de febrero, (<http://www.americaspolicy.org/reports/ 2004/0402nafta.html $>$, consultado el 28 de agosto de 2004).

IPCC (Intergovernmental Panel on Climate Change), 2001, Climate Change 2001: The Scientific Basis. Contribution of Working Group I to the Third Assessment Report of the Intergovernmental Panel on Climate Change. Technical Summary, WMO-UNEP, Cambridge University Press, Cambridge.

Kirkpatrick, A., 1996, "Role of the USA in Shortage of Food and Medicine in Cuba", The Lancet, vol. 348, noviembre, pp. 1489-1491.

Lean, G., D. Hinrichsen y A. Markham, 1990, Atlas of the Environment, Banson Marketing, Londres.

Macías, A., 2003, "Regiones hortícolas en México, ¿distritos agroindustriales o zonas de coyuntura agrícola?”, memoria in extenso publicada en las memorias del IV Congreso Internacional de la Red de Investigación sobre Flores, Frutas y Hortalizas (RISHORT), Las cadenas agroalimentarias de hortalizas, frutas y flores en América Latina, Guadalajara.

- 2006 , Empresarios, estrategias y territorio en la producción hortícola en México (el caso del valle de Sayula), tesis de doctorado, Centro de Investigaciones y Estudios Superiores en Antropología Social, México.

__ y A. Valenzuela, 2007, El campo económico del tequila en tiempos de globalización, ponencia a presentarse en el seminario Sistema Industria Tequila, SIT 2007, Guadalajara.

Maisterrena, J. e I. Mora, 2000, Oasis y espejismo. Proceso e impacto de la agroindustria del jitomate en el valle de Arista, S.L.P., SIHGO, El Colegio de San Luis, Gobierno del Estado de San Luis Potosí, San Luis Potosí.

Maxwell, S., 1996, "Food Security: A Postmodern Perspective”, Food Policy, vol. 21, núm. 2, pp. 155-170.

Mendelsohn, R., W. Nordhaus y D. Shaw, 1994, “The Impact of Global Warming on Agriculture: A Ricardian Analysis", The American Economic Review, vol. 84, núm. 4, septiembre, pp. 753-771.

— W. Worrison, M. Schlesinger y N. Andronova, 2000, "Country-Specific Market Impacts of Climate Change", Climatic Change, vol. 45, núm. 3-4, junio, pp. 553-569.

Moody, J. y V. García León, 2007, “Un maíz, dos mundos”, Expansión, núm. 959, 19 de febrero, pp. 62-72.

Moreno, J., 1997, "El uso del agua en los distritos de riego agrícola de Sonora, 1950 -1995. Los casos de la costa de 
Hermosillo, valle del Yaqui y valle del Mayo", ponencia presentada en el Simposio de Doctorado del Centro de Investigaciones y Estudios Superiores en Antropología Social-Occidente, Guadalajara, Jalisco.

Moser, C., 1996, Confronting Crisis. A Comparative Study of Household Responses to Poverty and Vulnerability in Tour Poor Urban Communities, The World Bank, Washington (Environmentally Sustainable Development Studies and Monographs Series, núm. 8).

Nadal, A., 2000a, "El caso del maíz mexicano en el NAFTA: variabilidad genética y liberalización comercial”, Biodiversidad, núm. 24, julio, pp. 3-12.

_ 2000b, The Environmental \& Social Impacts of Economic Liberalization on Corn Production in Mexico, WWF International, Oxfam GB, Gland, Suiza, y Oxford, Reino Unido.

- y T. Wise, 2004, The Environmental Costs of Agricultural Trade Liberalization: Mexico-U.S. Maize Trade under NAFTA, Working Group on Development and Environment in the Americas (Discussion Paper, núm. 4, junio).

Pellegino, A., 2003, La migración internacional en América Latina y el Caribe. Tendencias y perfiles de los migrantes, CEPAL, Celade, Santiago de Chile (Serie Población y Desarrollo, núm. 35).

Polanyi, K., 1957, The Great Transformation. The Political and Economic Origins of our Time, Beacon Press Books, Estados Unidos.

Quist, D. e I. Chapela, 2001, “Transgenic DNA Introgressed into Traditional Maize Landraces in Oaxaca, Mexico", Nature, núm. 414, 29 de noviembre, pp. 541-543.

Ramírez, C., 2003, "Historias de poder. Campiranos en la ciudad", Transición, 16 de febrero (<http:// www.lacrisis. com.mx/cgi-bin/cris-cgi/DisComuni.cgi?colum26|2003 0216013537>, consultado el 30 de mayo de 2007).

Redclift, M., 1997, "Sustainability and Theory: An Agenda for Action”, en D. Goodman y M. Watts (eds.), Globalizing Food. Agrarian Questions and Global Restructuring, Routledge, Nueva York.

Rifkin, J., 1999 [1998], El siglo de la biotecnología. El comercio genético y el nacimiento de un mundo feliz, Crítica Maracombo, Barcelona.

Rodríguez Gómez, G., 1998, "La apertura comercial y la actividad lechera en México”, en G. Rodríguez y P. Chombo (coords.), Los rejuegos del poder. Globalización y cadenas agroindustriales de la leche en Occidente, Centro de Investigaciones y Estudios Superiores en Antropología Social, México, pp. 35-57.

Schelling, T., 1993, "Economic Responses to Global Warming: Prospects for Cooperative Approaches", en R. Dorbusch y J. M. Poterba (eds.), Global Warming: Economic Policy Responses, MIT Press, Boston, pp. 197-221.
Schwentensius, R. y M. Gómez, 1998, “Competitividad de hortalizas mexicanas en el mercado norteamericano. Tendencias recientes en el marco del TLC", en Rita Schwentesius, M. A. Gómez Cruz y Gary W. Williams, TLC y agricultura, ¿Funciona el experimento?, Juan Pablos, México, pp. 167-203.

Semarnap (Secretaría del Medio Ambiente, Recursos Naturales y Pesca), 1998, México ante el cambio climático, México.

Sefoo, J. L., 1995, ¿Quién paga los platos rotos? Costos sociales de la agricultura moderna: el caso de las intoxicaciones por plaguicidas en Zamora, tesis de grado, El Colegio de Michoacán, Zamora, Michoacán.

SIAP (Servicio de Información Agroalimentaria y Pesquera), 2007, Situación actual y perspectivas del maíz en México, 1996-2012, Sagarpa, México.

Sevilla, E., 2006, "La agroecología como una alternativa hacia la sustentabilidad rural”, en J. Morales y J. Rocha (eds.), Sustentabilidad rural y desarrollo local en el sur de Jalisco, ITESO, Guadalajara, pp. 47-89.

Stanford, L., 1994, "Transitions to Free Trade: Local Impacts of Changes in Mexican Agrarian Policy", Human Organization, vol. 53, núm. 2, pp. 99-109.

Torres, F., 2003, "La visión teórica de la seguridad alimentaria como componente de la seguridad nacional", en F. Torres (ed.), Seguridad alimentaria: seguridad nacional, Universidad Nacional Autónoma de México, Plaza y Valdés, México, pp. 15-52.

_ y T. Aguilar, 2003, "Aspectos externos de la vulnerabilidad alimentaria de México”, en F. Torres (ed.), Seguridad alimentaria: seguridad nacional, Universidad Nacional Autónoma de México, Plaza y Valdés México, pp. 87-122.

Vaughan, S., 2003, “ ¿El tratado de comercio más verde de la historia? Medición del impacto ambiental de la liberalización agrícola”, en J. Audley, D. Papademetriou, S. Polaski y S. Vaughan, La promesa y la realidad del TLCAN. Lecciones para México y para el hemisferio, Carnegie Endowment for International Peace, Washington, pp. 65-94.

Vergara, R., 2007, “Agrava política agropecuaria la pobreza en el campo: ONG", Proceso, 27 de mayo $(<\mathrm{http}$ ://www. proceso.com.mx/noticia.html?sec $=1 \&$ nta $=50874 \& \mathrm{nsec}$ $=$ Nacional $>$, consultado el 30 de mayo de 2007).

Yunes-Naude, A., 2002, "Lessons from NAFTA: The Case for Mexico's Agricultural Sector", en Final Report to the World Bank, diciembre.

Wise, T., 2006, State of Emergency for Mexican Maize: Protecting Agro-biodiversity by Promoting Rural Livelihoods, ponencia presentada en el XXVIII Coloquio de Antropología e Historia Regionales "Desde los colores del maíz. Una agenda para el campo mexicano”, Zamora, Michoacán. 